\title{
Dermatofibrosarcoma Protuberans: Update on the Diagnosis and Treatment
}

\author{
Xingpei Hao ${ }^{1, *}$, Steven D. Billings ${ }^{2}$, Fangbai $\mathrm{Wu}^{3}$, Todd W. Stultz ${ }^{4}$, Gary W. Procop ${ }^{2}$, \\ Gene Mirkin ${ }^{1, *}$ and Allison T. Vidimos ${ }^{5, *}$ \\ 1 Foot and Ankle Specialists of the Mid-Atlantic, Rockville, MD 20850, USA \\ 2 Department of Pathology, Cleveland Clinic, Cleveland, OH 44195, USA; billins@ccf.org (S.D.B.); \\ procopg@ccf.org (G.W.P.) \\ 3 Department of Radiology, Cleveland Clinic, Cleveland, OH 44195, USA; WUF@ccf.org \\ 4 Imaging Institute, Section of Neuroradiology, Cleveland Clinic, Cleveland, OH 44195, USA; stultzt@ccf.org \\ 5 Department of Dermatology, Cleveland Clinic, Cleveland, OH 44195, USA \\ * Correspondence: xhao@footandankle-usa.com (X.H.); gmirkin@footandankle-usa.com (G.M.); \\ vidimoa@ccf.org (A.T.V.)
}

Received: 12 April 2020; Accepted: 4 June 2020; Published: 5 June 2020

\begin{abstract}
Dermatofibrosarcoma protuberans (DFSP) is a slow growing, low- to intermediate-grade dermal soft-tissue tumor. It has a high local recurrence rate but low metastatic potential. It is characterized by a uniform spindle cell arrangement, classically with a storiform pattern and CD34 immunoreactivity. The histomorphology and immunophenotype overlap with a broad range of other neoplasms. The standard treatment is complete surgical excision. The surgical procedures include wide local excision (WLE) with tumor free margins, Mohs micrographic surgery (MMS) and amputation. Unresectable DFSPs are treated with radiation therapy and/or targeted therapy. DFSP has characteristic $\mathrm{t}(17 ; 22)$ (q22; q13), resulting in a COL1A1- PDGFB fusion transcripts in more than $90 \%$ of DFSPs. Molecular detection of the gene rearrangement or fusion transcripts is helpful for the diagnosis of patients with atypical morphology and for screening candidates for targeted therapy with tyrosine kinase inhibitors. The aims of the present review are to update the clinical presentation, tumorigenesis and histopathology of DFSP and its variants for diagnosis and differential diagnosis from other benign and malignant tumors, to compare the advantages and drawbacks of WLE and MMS, to propose the baseline for selecting surgical procedure based on tumor's location, size, stage and relationship with surrounding soft tissue and bone structures, and to provide a biologic rationale for the systemic therapy. We further propose a modified clinical staging system of DFSP and a surveillance program for the patients after surgical excision.
\end{abstract}

Keywords: dermatofibrosarcoma protuberans; wide local excision; Mohs micrographic surgery; targeted therapy; pathology; tumorigenesis

\section{Introduction}

Dermatofibrosarcoma protuberans (DFSP), derived from dermal fibroblasts, was initially characterized as keloid sarcoma. It was named as DFSP by Hoffman in 1925 [1]. Clinically, it is a slow-growing, low- to intermediate-grade malignant sarcoma and frequently occurs in middle-aged adults. Histopathologically, it is composed of uniform spindle cell fascicles growing in a storiform pattern with multiple variants and with strong and diffuse CD34 immunoreactivity. However, its spindle cell morphology and CD34 immunostaining pattern are overlapped with other benign and malignant lesions, which must be differentiated from. Ultrastructurally, DFSP is characterized by stellate or spindle cells, with long, slender, ramified cell processes joined by primitive junctions, 
which are similar to dermal dendrocytes [2]. Cytogenetically, more than $90 \%$ of DFSP have at $(17 ; 22)$ (q22; q13), leading to the formation of COL1A1-PDGFB fusion transcripts. Molecular detection of gene rearrangements or fusion transcripts is beneficial not only for the diagnosis in cases without typical morphology, but also for screening patients who are candidates for using imatinib mesylate (a tyrosine kinase inhibitor that affects PDGF $\beta$ R). This provides neoadjuvant targeted therapy for the patients with unresectable, recurrent or metastatic DFSP [3]. The standard treatment of resectable DFSPs is complete surgical excision with either wide local excision with tumor free margins or Mohs micrographic surgery, or, rarely, amputation. Each procedure has advantages and drawbacks. Unresectable DFSPs are treated with radiation therapy and/or targeted therapy. Accordingly, we update the DFSP's clinical manifestations, histological features with its variants, diagnosis, differential diagnosis and tumorigenesis. We discuss the advantages and drawbacks of different surgical procedures for resectable tumors and the width of margin resection. We review the biologic rationales of radiation therapy and/or targeted therapy for unresectable tumors. We also propose a modified staging system of DFSP for clinical practice and a surveillance program to monitor local recurrence and metastasis after surgical excision.

\section{Epidemiology}

DFSP is an uncommon, indolent dermal soft-tissue sarcoma that accounts for less than $0.1 \%$ of all malignancies and less than $1 \%$ of all soft-tissue sarcomas [4-6]. Two large epidemiological studies in the United States demonstrated that the annual incidence of DFSP was 4.2 per million people studied in a 30-year period from 1973 to 2002 [7], and 4.1 per million people in a 10-year period between 2000 and 2010 [8]. The incidence of DFSP is higher in women than men, and higher in African-American than white patients $[4,5]$. It most frequently occurs in young and middle-aged patients, between 25 and 45 years of age, with a mean age between 40 to 43 years $[9,10]$. However, patient's age ranged widely from infancy to the elderly [11-13].

\section{Pathogenesis}

Cytogenetic and molecular studies have demonstrated that more than $90 \%$ of DFSPs are characterized by either supernumerary ring chromosomes derived from chromosomes 17 and 22 or chromosomal translocation $\mathrm{t}(17 ; 22)$ (q22; q13), resulting in the fusion of collagen type 1-alpha $1(C O L 1 A 1$ at $17 \mathrm{q} 22)$ and platelet-derived growth factor beta (PDGFB at 22q13) genes. The gene fusion places the PDGFB gene under the control of the COL1A1 promoter [14-16], leading to PDGF $\beta$ overexpression and dimerization, and subsequently resulting in continuous activation of the PDGF receptor $\beta$ protein-tyrosine kinase [17]. Interaction of PDGF $\beta$ and PDGF receptor $\beta$ is involved in multiple signaling pathways including Ras mitogen-activated protein kinases (RAS-MARK) and phosphatidylinositol 3-kinase-akt-rapamycin (mTOR) (PI3K-AKT-mTOR) [18-21]. Correspondingly, increased expression of the phosphorylated Akt-mTOR pathway proteins including Akt, mTOR, 4 EBP1, and S6RP and phosphor-PDGFR $\alpha / \beta$ have been demonstrated in about half of DFSP tissues by immunoperoxidase studies [21], suggesting that Akt-mTOR pathways are involved in the tumorigenesis of DFSP. Gene fusion transcript of COL1A1-PDGFB can be detected by either fluorescent in situ hybridization (FISH) or multiplex reverse transcriptase-polymerase chain reaction (RT-PCR) in formalin fixed, paraffin embedded tissues [22,23]. These are helpful for the diagnosis, differential diagnosis and guiding treatment of DFSP [24], especially when the tumor's histomorphology is not typical or when the tyrosine kinase inhibitors are considered for treatment. The COL1A1-PDGFB fusion transcript cannot be detected in about $8 \%$ of DFSPs [15]. FISH analysis revealed genetic translocations involving the CSPG2 gene at $5 \mathrm{q} 14.3$ and PTK2B gene at $8 \mathrm{p} 21.2$ in a patient of DFSP without the COL1A1-PDGFB fusion transcript [16]. Other reported genetic translocations in DFSP include COL1A2-PDGFB [3], COL6A3-PDGFD [25] and elastin microfibril interface 2 (EMILIN2)-PDGFD [26]. Moreover, p53 mutation and overexpression, murine double minute 2 (MDM2) overexpression were reported in fibrosarcomatous variant of DFSP $[17,27]$. Furthermore, DFSPs were reported in 
patients with immunodeficiency disorders, including X-linked agammaglobulinemia [28], adenosine deaminase-deficient severe combined immune deficiency [29], ataxia telangiectasia syndrome [30] and HIV infection [31]. In addition, pregnancy may increase the risk for the development of DFSP [32]. These data suggest that multiple factors including oncogenes, tumor suppressor genes and immunodeficiency are involved in the development of DFSP. Further investigation is required to understand the relationship of these risk factors to the development of DFSP.

\section{Clinical Characteristics}

In early stages of DFSP, the patient typically notices a slow-growing, small, firm, painless, skin-colored dermal plaque (Figure 1A,B), subcutaneous thickening or atrophic non-protuberant lesion [33,34]. Early pediatric DFSPs were classified into four variants: (1). Small palpable nodules slowly forming a confluent sclerotic plaque; (2). Keloid-like homogenous cutaneous thickening plaque; (3). Tumor ab initio and (4). Atrophic plaque [35]. Congenital DFSPs were reported as either erythematous atrophic plaque or irregular shaped, pigmented macula resembling melanocytic nevus after birth [34,36]. These congenital DFSPs carried the COL1A1-PDGFB fusion detected by either RT-PCR or FISH [34,36]. The early non-protuberant lesions gradually enlarge to form protuberant, indurated, reddish-blue or violaceous nodules in protuberant stages (Figure 2A-C). If untreated, the tumors can locally invade more deeply into the fascia, muscle, periosteum, bone and occasionally metastasize to other organs in advanced stages [37]. The tumor cells most frequently metastasize to lung, brain, bone, visceral organs, lymph nodes and soft tissues [13,38-40]. This insidious growing process takes several months or years to as long as 60 years $[13,33,34]$. The reported tumor sizes vary in a wide range from 0.5 to $>10 \mathrm{~cm}$ in diameter, with a mean of 2-3.5 cm [41,42]. Most DFSPs are localized on the trunk (40-50\%), followed by proximal extremities (30-40\%), and then the head and neck (10-15\%) [43-45]. Infrequently documented cases have been reported on the toes [22,46-49], scalp [50], breast [51-53] and vulva [54].

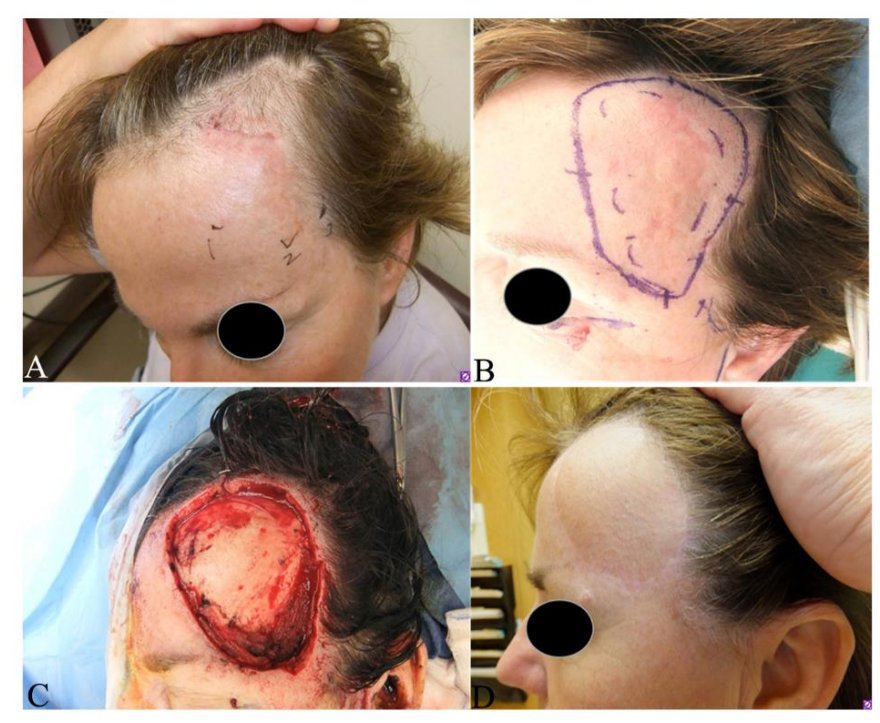

Figure 1. Clinical presentation and Mohs micrographic surgery (MMS) of a female patient with a primary fibrosarcomatous-dermatofibrosarcoma protuberans. (A) Asymptomatic, ill-defined plaque on her left frontal scalp, with scouting biopsies at inferior aspect; preoperative magnetic resonance imaging showed no bony invasion (Figure 3), PET CT showed no local or distant metastases; (B) surgical marks for MMS. The inner dashed lines indicate the palpable and pathologically positive tumor boundaries while the solid outer lines indicate the surgical incision with the first Mohs layer; (C) wound after first stage of Mohs surgery, all deep and peripheral margins were clear; (D) postoperative at 12 months following a free flap repair. Currently 9 years postop with no evidence of recurrence. 


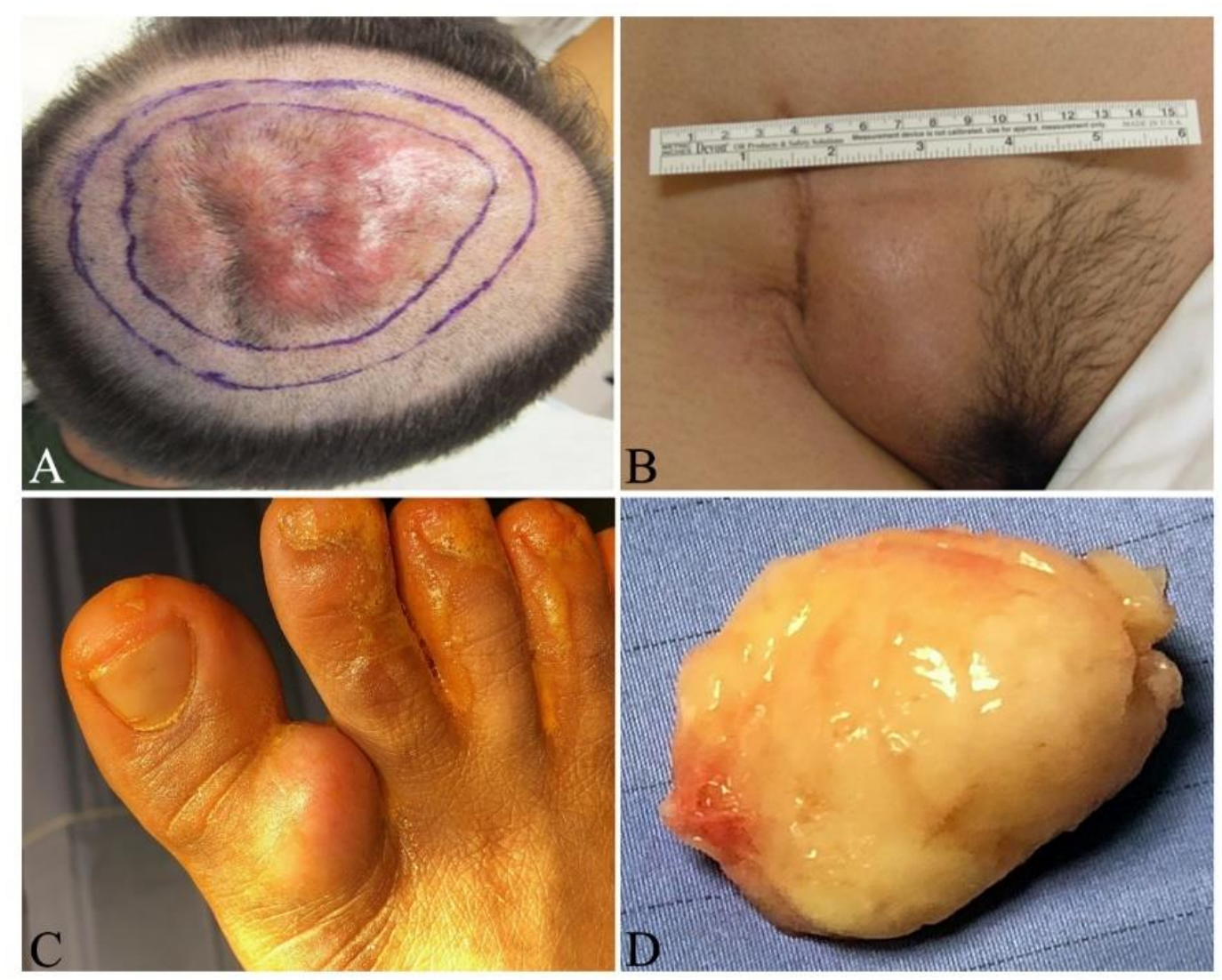

Figure 2. Clinical presentation of dermatofibrosarcoma protuberans. (A) Multiple, raised, erythematous, confluent nodules on the vertex of the scalp from an adult male. The inner circle indicates the palpable tumor boundary and the outer line indicates the surgical excision during Mohs surgery; (B) recurrent, skin colored, raised mass around the scar in the right lower abdomen from an adult female; (C) skin-colored, raised tumor on the lateral side of the right hallux from an adult male; (D) white to yellow, solid, fish flesh-like soft tissue mass enucleated from figure $\mathrm{C}$ with patient's agreement. Tumor cells were observed on all margins. The patient was referred to an oncologist for radiation therapy since any further invasive surgery was declined.

\section{Clinical and Imaging Evaluation}

In addition to a thorough history and physical examination, diagnosis of suspected DFSP ideally requires a generous biopsy (punch biopsy or excisional biopsy) for a pathologic diagnosis. The pathology report should note the presence of fibrosarcomatous change or other high-risk features. Examination of lymph nodes and imaging studies are important for staging and surgical planning.

Magnetic resonance imaging (MRI) delineates tumor's size and extent, and its relationship with adjacent neuromuscular structures and bone (Figures 3, 4 and 5A,B). MRI is therefore recommended for pre-operative evaluation, surgical planning and follow-up for recurrence [55,56]. MR T1-weighted images exhibit well-defined homogeneous isointense lesions, while T2-weighted images show a well-defined subcutaneous soft tissue nodules or mass with intermediate-to-marked homogeneous hyperintensity to the surrounding muscular tissues (Figure 4A,B) [57]. Poorly defined irregular margins can be observed in some cases (Figure 4B) [58]. High frequency ultrasound can be used to evaluate the extent of the tumor involvement as well as provide biopsy guidance. The ultrasound of DFSP often appears as a hypoechoic superficial nodular mass [59,60]. Computed tomography (CT) reveals a solitary, subcutaneous lobular or nodular architecture and soft tissue attenuation and post-contrast enhancement (Figure 5C,D) [61]. Intratumoral non-enhancement areas in large tumors $(>5 \mathrm{~cm})$ may suggest necrosis and cystic degeneration. $\mathrm{CT}$ is useful to evaluate distant metastatic disease. The technique of 18F-fluorodeoxyglucose-positron emission tomography/computed tomography 
$\left({ }^{18} \mathrm{~F}-\mathrm{FDG}\right.$ PET/CT) has shown potential value in both identifying metastatic disease and evaluating treatment response [61-63]. X-rays have no role in the imaging of the primary DFSP.

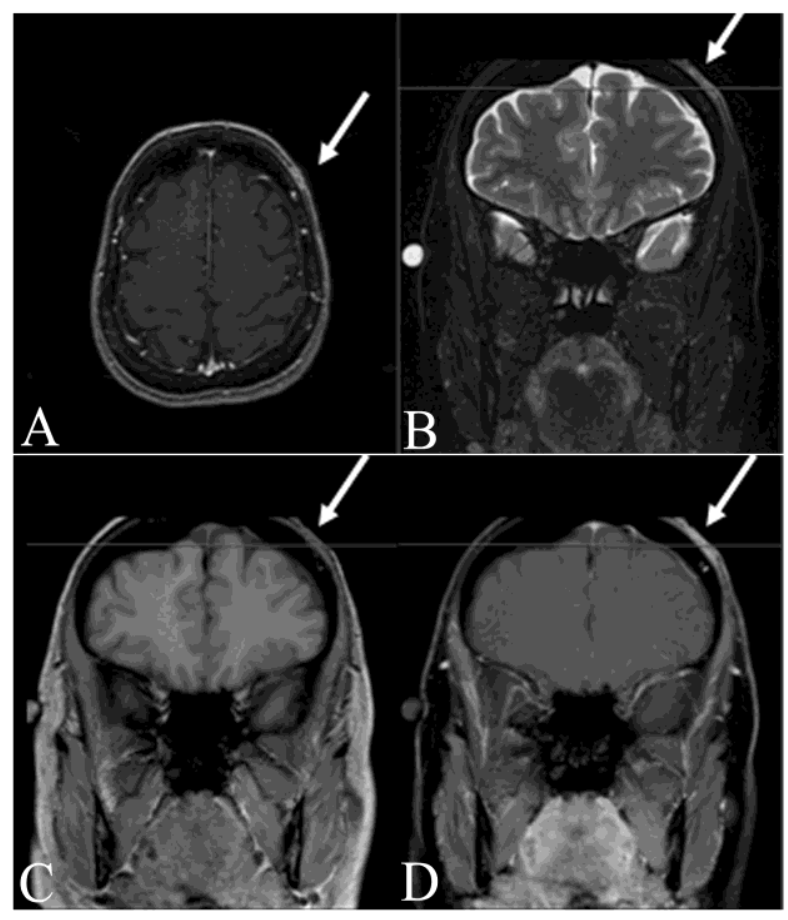

Figure 3. Magnetic resonance imaging of fibrosarcomatous-dermatofibrosarcoma protuberans on the left forehead from patient in Figure 1. (A) Left scalp enhancement (arrow) in axial post-gadolinium thin slice image; (B) left scalp hyperintensive lesion without bony invasion (arrow) on coronal fat saturated T2-weighted image; (C) left scalp isointense lesion (arrow) before gadolinium on T1-weighted image; (D) left scalp hyperintense lesion (arrow) after gadolinium on T1-weighted image.

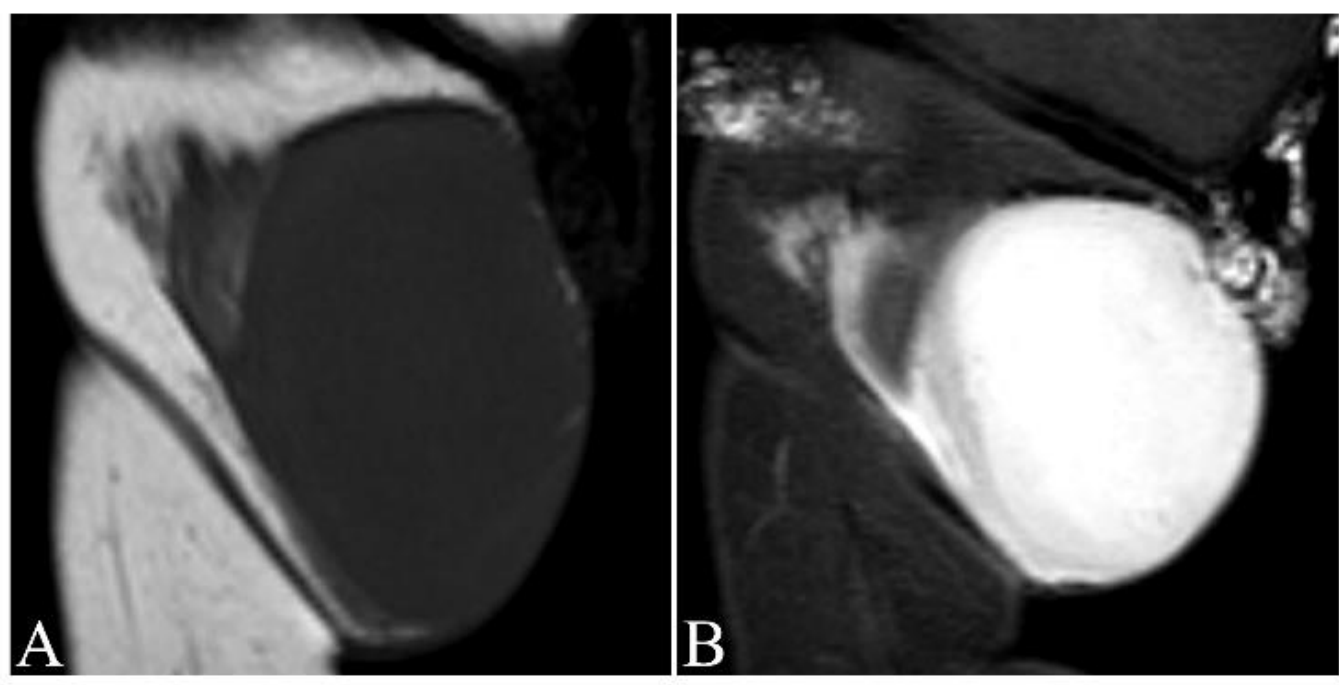

Figure 4. Magnetic resonance imaging (MRI) of dermatofibrosarcoma protuberans on the left thigh of an 8-month-old girl. (A) MR T1-weighted image exhibiting well-defined homogeneous isointense lesion; (B) T2-weighted image showing a well-defined mass with intermediate-to-marked homogeneous hyperintensity with infiltration of the adjacent fat plane and encasement of the gracilis muscle at the level of this image. 


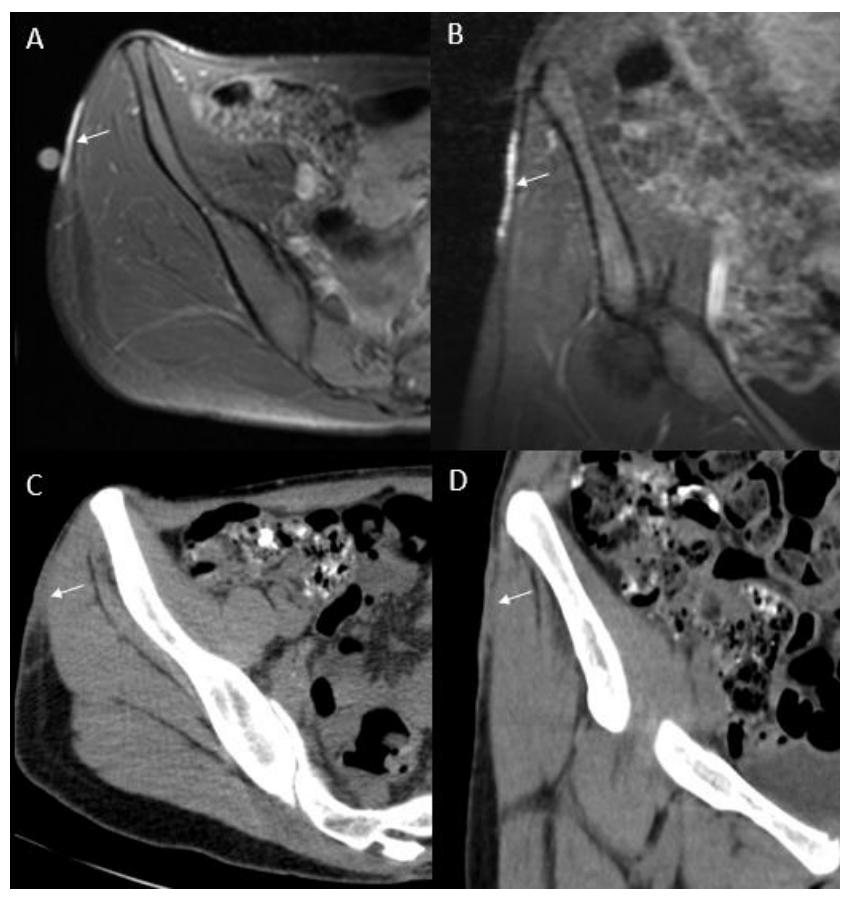

Figure 5. Magnetic resonance imaging (MRI) and computed tomography (CT) of a locally recurrent dermatofibrosarcoma protuberans (DFSP) of the right hip. (A) axial and (B) coronal MR T1-weighted fat suppressed post-contrast images of the right hip show enhancing tumor (arrows) diagnosed as a recurrent DFSP; (C) axial and (D) coronal corresponding images from non-contrast CT demonstrate soft tissue attenuation of the tumor (arrows).

\section{Pathologic diagnosis}

Grossly, DFSP is commonly a white to yellow color, poorly circumscribed, soft-tissue mass without a smooth outer surface. The cut surface is white to yellow, poorly encapsulated, solid and a fish flesh-like texture (Figures 2D and 6). Hemorrhagic and/or cystic changes can be observed in larger tumors $(>5 \mathrm{~cm})$. All sides of margins need to be labeled and grossed to examine if any part of the margins contains tumor cells or not (Figure 6).

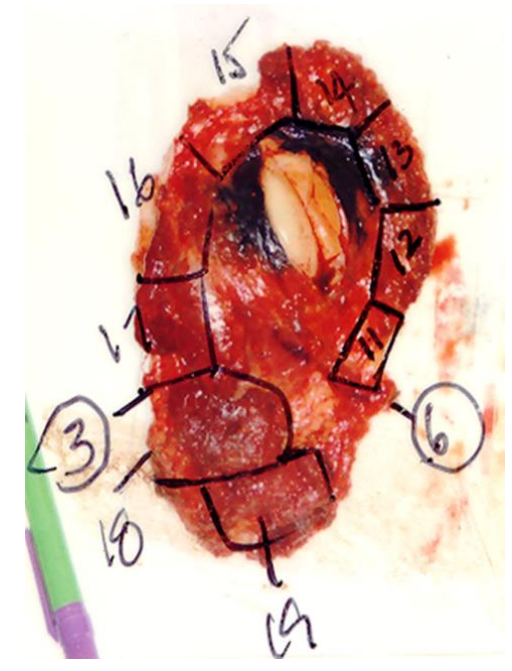

Figure 6. Photograph of pathologic grossing and mapping of the deep tumor margins during Mohs surgery for a dermatofibrosarcoma protuberans. All of the tumor margins were labeled and grossed to examine the residual tumor cells. 
Histologically, DFSP is derived from fibroblasts in the dermis and subsequently it can infiltrate into the subcutaneous tissues or it can develop directly from subcutaneous tissues [64]. In non-protuberant stage I with dermal plaque or subcutaneous thickening, the elongated spindle cells are loosely scattered in the upper dermis without involving grenz zone (Figure 7A). In stage II and later with protuberant lesions, DFSP is typically featured with uniformly monomorphous spindle cells, with little atypia and mitotic activity, arranged in a storiform pattern, in the subcutaneous and dermal layers (Figure 7C). The cellular nuclei are elongated with mild hyperchromasia, small to inconspicuous nucleoli and low to moderate quantities of cytoplasm. The neoplastic cells often infiltrate into subcutaneous adipose tissue in a honeycomb pattern (Figure 7D). This poses challenge to determine the true extent of the tumor tissue. All margins need to be carefully grossed and examined for residual tumor cells (Figure 6). Immunohistochemically, spindle cells typically show strong and diffuse cytoplasmic expression of CD34 (Figure 7B), but negative expression for other immunohistochemical stains, such as alpha-smooth muscle actin, factor XIIIa, S-100 and melan-A. It should be noted that CD34 expression could be reduced or even lost in up to $45 \%$ of the fibrosarcomatous DFSP (Figure 7I) [13,65]. CD34 expression is not unique to DFSP. Other tumors, including spindle cell lipomas, fibromas, fibromyxomas and Kaposi sarcomas, also express CD34.

DFSPs have multiple histological variants including myxoid (Figure 7E), pigmented, giant cell (Figure 7F), giant cell fibroblastoma, granular cell, sclerotic (Figure 7G) and fibrosarcomatous (FS) component (Figure 7H, Table 1). These variants reflect the morphologic heterogeneity which is associated with the spindle cell differentiation during tumor development. They do not bear significant clinical manifestations and outcomes, except for the FS variant with increased risk of local recurrence and metastatic potential [28].

DFSP without FS component is categorized as classic or conventional DFSP, accounting for $80-90 \%$ of all DFSPs [66]. It is considered a low-grade malignancy with a propensity of local recurrences following resection, but almost no metastatic potential $[67,68]$. FS-DFSP is featured with atypical spindle cells with significantly increased mitotic activity arranged in a herringbone pattern (Figure 7H), often with reduced or even loss of CD34 expression (Figure 7I), but increased Ki-67 expression (a marker of cellular proliferation) [13]. FS-DFSPs consisting of $10-20 \%$ of DFSPs are considered intermediate-grade sarcoma with a higher metastatic risk (5-15\%) [13,67]. Analysis of 24 reports containing 1422 patients with DFSP and 225 with FS-DFSP revealed that FS-DFSPs, compared with classic DFSPs, had a significantly higher risks of local recurrence $(29.8 \%$ vs $13.7 \%$, risk ratio 2.2 (95\% confidence interval 1.7-2.9)); metastasis ( $14.4 \%$ vs $1.1 \%$, risk ratio 5.5 (95\% confidence interval $4.3-7.0)$ ); and death from disease ( $14.7 \%$ vs $0.8 \%$, risk ratio 6.2 (95\% confidence interval 5.0-7.8)) [66]. 

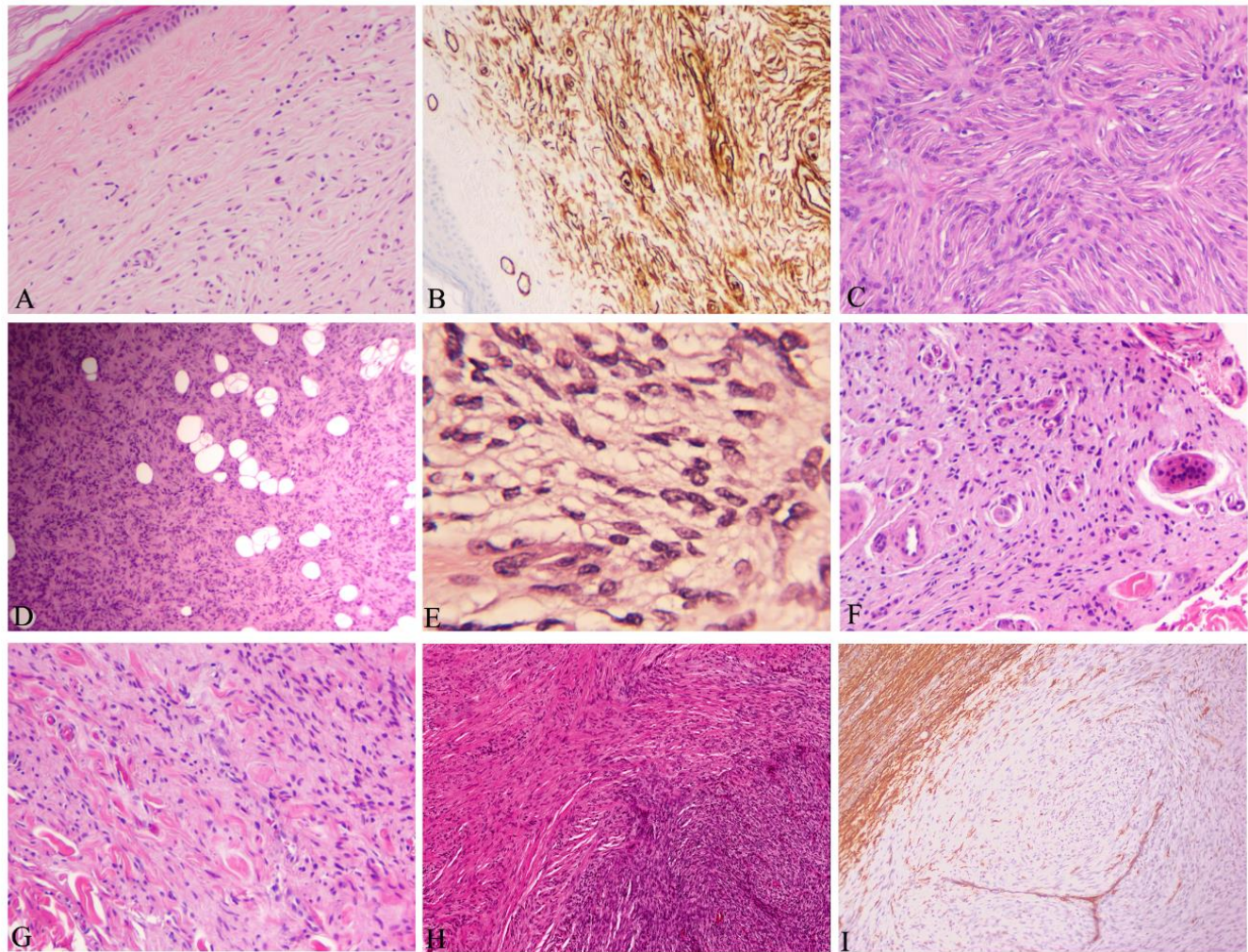

Figure 7. Histopathology of dermatofibrosarcoma protuberans. (A) Elongated spindle cells loosely scattered in the upper dermis without involving grenz zone in early stage (dermal plaque) $(\mathrm{HE}, 40 \times 1)$; (B) diffuse and strong CD34 immunostaining in spindle cells (same case as A, DAB, $40 \times 1$ ); (C) dense spindle cells in a storiform $(\mathrm{HE}, 100 \times 1)$; (D) spindle cells infiltrating into surrounding fatty tissues forming a honeycomb-like structure $(\mathrm{HE}, 40 \times 1)$; (E) myxoid variant: Spindle cells in the myxoid stroma $(\mathrm{HE}, 100 \times 1)$; (F) giant variant: Polymorphic and giant cells admixed with spindle cells (HE, $100 \times 1)$; (G) sclerotic variant: Less than $50 \%$ of spindle cells in the hypocellular collagenous stroma $(\mathrm{HE}, 100 \times 1)$; $(\mathbf{H})$ fibrosarcomatous component (right lower part) with increased atypia of cellularity, hyperchromasia and mitosis in a transition from classic DFSP (upper left part) $(\mathrm{HE}, 100 \times 1)$; (I) loss of CD34 expression in fibrosarcomatous components compared with classic DFSP part where CD34 was strongly expressed (upper left part, same case as H) $(\mathrm{DAB}, 100 \times 1)$.

Table 1. Histopathologic features of different dermatofibrosarcoma protuberans variants.

\begin{tabular}{|c|c|}
\hline Variants. & Histopathologic Features \\
\hline Myxoid & $\begin{array}{l}\text { Elongated, infiltrative spindle cells with myxoid changes in stroma (Figure 7E); } \\
\qquad{\mathrm{CD} 34^{+} \text {, alpha smooth muscle actin-, desmin }}^{-}\end{array}$ \\
\hline Pigmented (Bednář tumor) & $\begin{array}{l}\text { Spindle cells admixed with scattered, single or a small cluster of dendritic } \\
\text { melanin-containing cells [69]; CD34 }{ }^{+} ; \mathrm{S}-100^{+} \text {and } \mathrm{HBM}^{+} 5^{+} \text {in pigmented cells }\end{array}$ \\
\hline Giant cell (Rare) & $\begin{array}{l}\text { Spindle cells admixed with pleomorphic or multinucleated giant cells } \\
\text { (Figure } 7 F)[70,71] ; \text { CD34 } \\
\end{array}$ \\
\hline $\begin{array}{l}\text { giant cell fibroblastoma (GCF) } \\
\text { (commonly seen in the pediatric population) }\end{array}$ & $\begin{array}{l}\text { Parallel fascicles of wavy uniform spindled cells with wiry collagen, dense } \\
\text { sclerosis and pseudovascular spaces with scattered and rimming pleomorphic } \\
\text { giant cells [71]. GCF shares the same genetic abnormality as DFSP and the } \\
\text { recurrent cases of GCF show histological features of DFSP [72-76] }\end{array}$ \\
\hline Granular cell (Rare) & $\begin{array}{l}\text { Spindle cells admixed with a proportion of cells with eccentric round nuclei, } \\
\text { prominent nucleoli and abundant lysosomal granules }[77] ; \mathrm{CD} 34^{+} \text {, natural } \\
\text { killer cell inhibitory factor } 1 \mathrm{C}^{+}\end{array}$ \\
\hline Sclerotic (Rare) & $\begin{array}{l}\text { Spindle cells embedded in more than half of hypocellular collagenous } \\
\text { components [78] (Figure 7G), CD34 }{ }^{+}\end{array}$ \\
\hline Fibrosarcomatous (13.5\%) [66] & $\begin{array}{l}\text { Increased spindle cells with atypia, increased mitotic figures; fascicular or } \\
\text { herringbone rather than storiform pattern; necrosis occasionally observed } \\
\text { (Figure } 7 \mathrm{H} \text { ) [66]; reduced or even lost CD34 expression (Figure 7I) [13] }\end{array}$ \\
\hline
\end{tabular}




\section{Differential diagnosis}

Similarities in clinical manifestations and overlaps in histopathologic and CD34 immunostaining profiles with other tumors require DFSP to be differentiated from other benign and malignant lesions including dermatofibroma, schwannoma, cutaneous neurofibroma, solitary fibrous tumor, intradermal spindle cell lipoma and spindle cell or desmoplastic melanoma. Detailed evaluation of the clinical presentation and morphologic features with immunohistochemistry are needed to make an accurate diagnosis (Table 2). Difficult cases can be further tested by molecular techniques including FISH and RT-PCR to detect gene rearrangements and gene fusion transcripts in formalin fixed, paraffin embedded tumor tissues [79].

Table 2. Differential diagnosis of dermatofibrosarcoma protuberans.

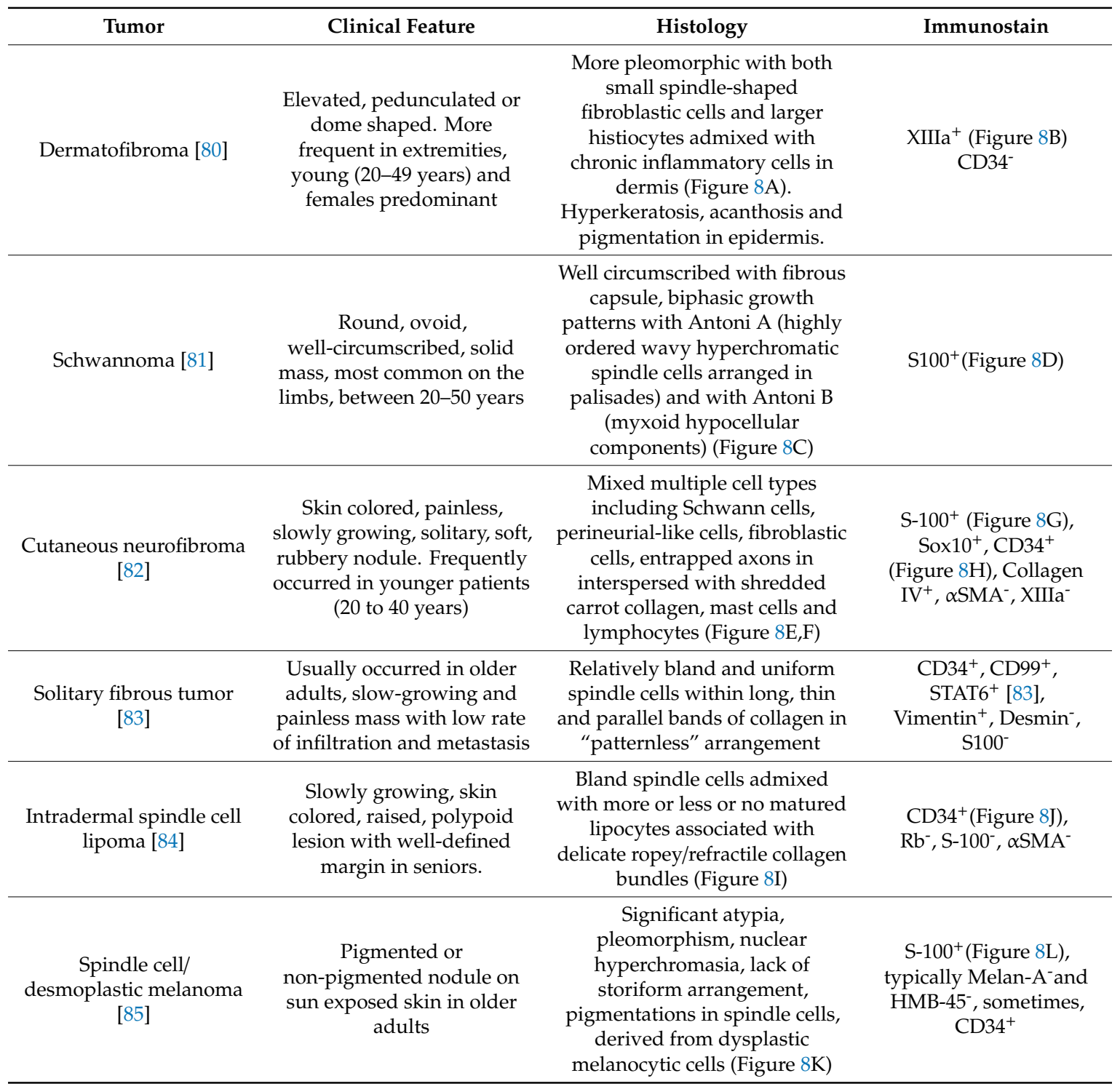



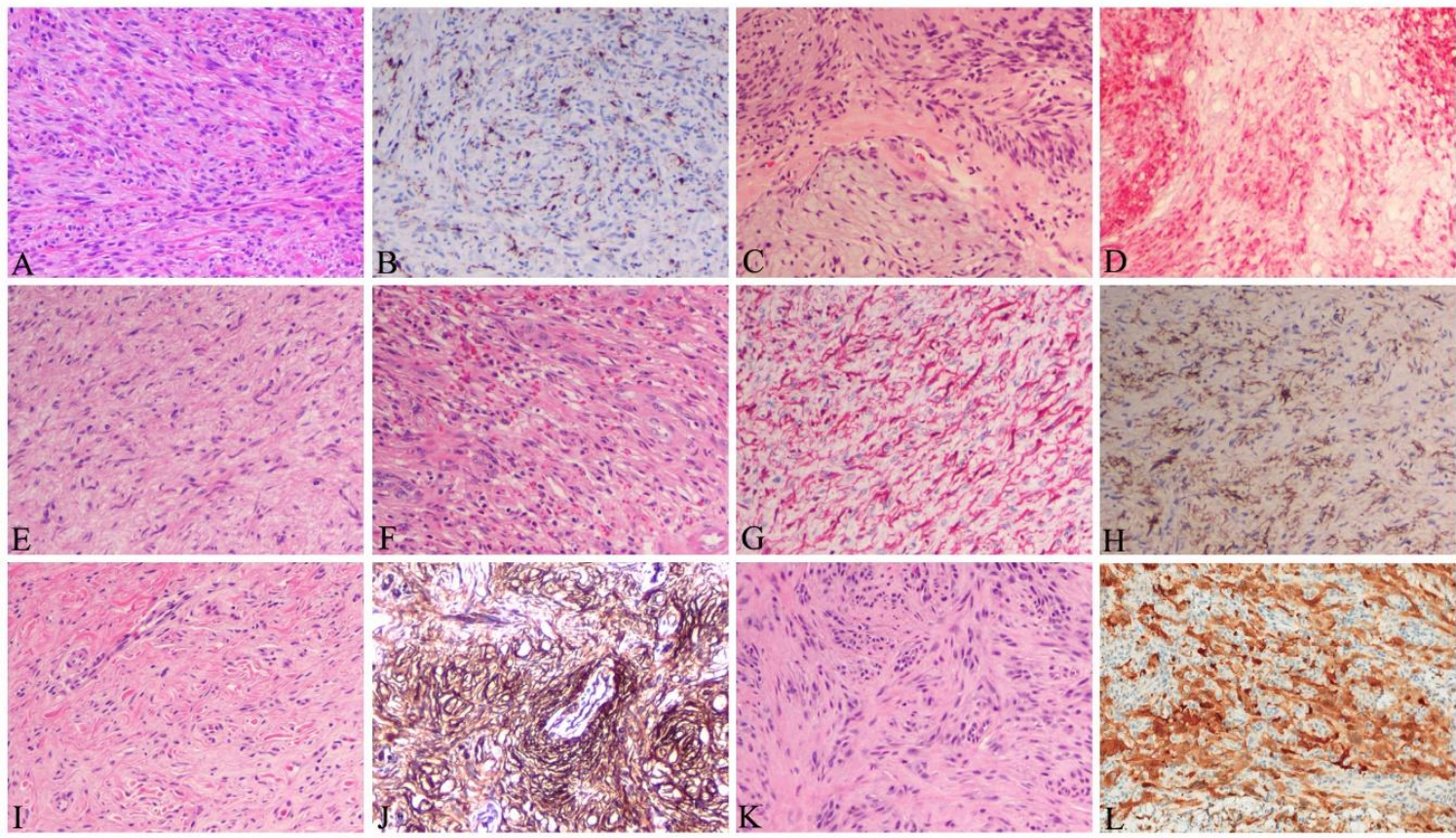

Figure 8. Histopathology of different tumors differentiated from dermatofibrosarcoma protuberans. (A) Dermatofibroma: Interlacing fascicles of spindle shaped fibroblasts and histiocytic cells mixed with collagens $(\mathrm{HE}, 100 \times 1)$; $($ B $)$ factor XIIIa expression in dermatofibroma (same tissue as A, DAB, $100 \times 1$ ); (C) schwannoma: wavy hyperchromatic spindle cells arranged in palisades (Antoni A, upper part) and myxoid hypocellular components (Antoni B, lower part) $(\mathrm{HE}, 100 \times 1)$; (D) S-100 expression in schwannoma (same tissue as $\mathrm{C}$, alkaline phosphatase red, $100 \times 1)$; (E) neurofibroma: bland serpentine spindle shaped cells and shredded carrot collagens $(\mathrm{HE}, 100 \times 1)$; (F) neurofibroma: mast cells and lymphocytes interspersed among the spindle cells and tumor stroma (same tissue as $\mathrm{E}, \mathrm{HE}, 100 \times 1$ ); (G) S-100 expression in neurofibroma (same tissue as E, alkaline phosphatase red, $100 \times 1$ ); (H) CD34 expression in neurofibroma (same tissue as $\mathrm{E}, \mathrm{DAB}, 100 \times 1)$; (I) spindle cell lipoma: bland spindle cells without matured lipocytes embedded in ropey/refractile collagen bundles (HE, $100 \times 1)$; (J) CD34 expression in spindle cell lipoma (same tissue as I, DAB, $100 \times 1)$; $(\mathbf{K})$ melanoma: spindle shaped cells with light scattered pigments $(\mathrm{HE}, 100 \times 1)$; (L) S-100 expression in spindle cell melanoma (DAB, $200 \times 1)$.

\section{Clinical Staging System}

No standard staging system of DFSP is available [86]. We propose a modified staging system of DFSP based on European consensus-based interdisciplinary guideline [86], the progression of DFSPs' tumorigenesis and clinical presentation, as shown in Table 3. This staging system is useful for treatment.

Table 3. Staging system of dermatofibrosarcoma protuberans.

\begin{tabular}{cc}
\hline Stage & Criteria \\
\hline Stage I & Non-protuberant lesions including atrophic or sclerotic plaque, macula or small nodules \\
\hline Stage II & Protuberant primary tumor \\
\hline Stage IIA & Superficial tumor: without invasion of the underlying fascia \\
\hline Stage IIB & Deep tumor: either superficial to the fascia with infiltrating the fascia or occurred beneath \\
& the superficial fascia \\
\hline Stage III & Lymph node metastasis \\
\hline Stage IV & Distant metastasis to other organs \\
\hline
\end{tabular}




\section{Treatment}

\subsection{Treatment of Resectable DFSP}

Surgical excision is the standard treatment of DFSP including stage I and II, even III and IV whenever feasible. Wide undermining following surgical excision is not advisable as it may seed tumor in incomplete resections and also may cause difficulty in interpreting subsequent re-excisions. Initial resected tumors with positive margins or relapsed/recurrent tumors need to be further resected to achieve wide clear margins whenever possible [41]. Surgical reconstruction should be delayed until all margins are confirmed negative by complete peripheral and deep margin examination. If concern exists for positive surgical margins following wide excision, a split thickness skin graft may be placed to facilitate monitoring for recurrence.

Surgical techniques include wide local excision (WLE) with tumor-free margins, Mohs micrographic surgery (MMS) (Figures 1B-D and 9B-D), partial or total amputation if the tumor is located on the upper or lower digits $[28,87,88]$. Both WLE and MMS are used in the clinical practice and each has advantages and drawbacks, as summarized in Table 4.

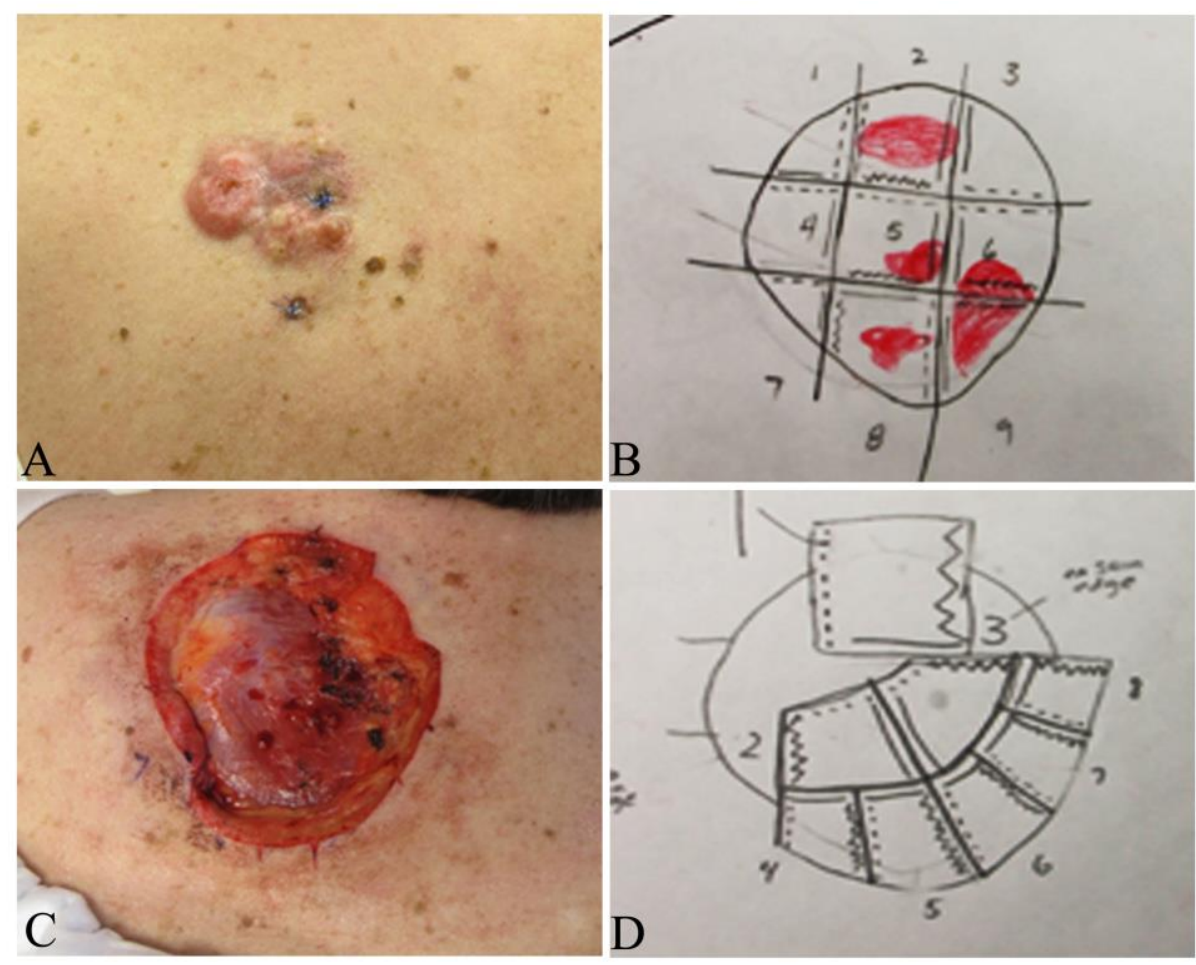

Figure 9. Clinical presentation and Mohs map in a patient with a primary dermatofibrosarcoma protuberans on the back. (A) Several irregular, firm confluent nodules on the left upper back; (B) Mohs map of A for the first stage dissection; (C) surgical surface after the primary tumor was dissected out; (D) Mohs map of the second stage dissection. 
Table 4. Comparison between wide local excision (WLE) and Mohs micrographic surgery (MMS).

\begin{tabular}{|c|c|c|}
\hline Comparable Parameter & WLE & MMS \\
\hline Surgical procedures $[87,88]$ & $\begin{array}{l}\text { A three-dimensional excision } \\
\text { including normal skin, } \\
\text { subcutaneous tissue and the } \\
\text { underlying investing fascia within } \\
\text { a } 2-4 \mathrm{~cm} \text { margins from the gross } \\
\text { tumor boundary }\end{array}$ & $\begin{array}{l}\text { A stepwise procedure of tumor removal } \\
\text { with mapping, histopathologic } \\
\text { examination of } 100 \% \text { of the margins with } \\
\text { tangential frozen sections by the Mohs } \\
\text { surgeon and further deeper and/or wider } \\
\text { re-excision of another layer of } \\
\text { surrounding tissues if residual tumor cells } \\
\text { are visualized. This procedure is repeated } \\
\text { until all tumor margins are free of tumor } \\
\text { cells. Usually performed as an outpatient } \\
\text { with local anesthesia (Figure 9) }\end{array}$ \\
\hline Advantages [87] & $\begin{array}{l}\text { Relative simpler procedure } \\
\text { Immediate wound repair } \\
\text { following tumor removal } \\
\text { Cost effective for patients and } \\
\text { medical resources (but additional } \\
\text { cost is incurred if positive margins } \\
\text { need to be addressed) }\end{array}$ & $\begin{array}{c}\text { Precise and complete evaluation of } 100 \% \\
\text { of the surgical margins during excision; } \\
\text { wound repair done when clear margins } \\
\text { are obtained } \\
\text { Lower rates of local recurrence compared } \\
\text { with surgical excision }\end{array}$ \\
\hline Drawbacks [87] & $\begin{array}{l}\text { Unable to evaluate surgical } \\
\text { margins during surgical operation } \\
\text { Higher rate of local recurrences } \\
\text { compared to Mohs surgery }\end{array}$ & $\begin{array}{c}\text { Needs specialized training for Mohs } \\
\text { surgeons and coordination with in office } \\
\text { histotechnologists } \\
\text { Delayed closure (usually same day) to } \\
\text { allow for pathologic evaluation } \\
\text { Time consuming and labor intensive } \\
\text { May have higher cost for patients and } \\
\text { medical resources }\end{array}$ \\
\hline Applications [89] & $\begin{array}{l}\text { Best for primary DFSPs on the } \\
\text { trunk or extremities with a } 2-4 \mathrm{~cm} \\
\text { margin from tumor boundary to } \\
\text { completely excise tumor with } \\
\text { acceptable cosmesis and function } \\
\text { in a single operation }\end{array}$ & $\begin{array}{l}\text { Ideal for DFSPs in cosmetically and } \\
\text { functionally sensitive regions including } \\
\text { face, scalp, neck, genitalia and digits to } \\
\text { preserve tissue for optimal cosmetic } \\
\text { reconstruction and functional recoveries } \\
\text { and may be utilized in trunk and } \\
\text { extremity DFSP }\end{array}$ \\
\hline
\end{tabular}

Multiple studies have shown that MMS can significantly lower the risk of recurrence of DFSP, compared with WLE $[88,90,91]$. A comprehensive retrospective meta-analysis involving 684 patients of DFSP published on Medline from 2008 to 2018 revealed that the recurrence rates of DFSP treated with WLE and MMS were $9.10 \%$ and $2.72 \%$, respectively, with mean follow-ups of 5.32 years for both groups [92]. Lowe et al. reported the Mayo Clinic experience illustrating a 30.8\% recurrence rate following WLE and 3.0\% with Mohs surgery; primary closure was performed following MMS in $73 \%$ of cases, vs. flaps, graft and other closures in 52\% of the WLE cases [90]. Multidisciplinary management is advantageous with infiltrative DFSP of the head and neck as well as large tumors on the trunk, where the Mohs surgeon does the tumor mapping and histologic examination of all tumor margins in concert with another ablative surgeon (Figure 9) [93].

The width of the tumor free margins is an important factor to be considered for complete excision for both WLE and MMS. However, no agreement on optimal width of margins is available. NCCN guidelines (version 1.2020) suggest $2-4 \mathrm{~cm}$ lateral margins from the tumor and the excision of the investing fascia to remove any infiltrating tumor in WLE [94]. Ratner et al analyzed records of 58 patients with primary and recurrent DFSP treated with Mohs surgery and reported that $70 \%$ had positive margins with a $1 \mathrm{~cm}$ margin, $39.7 \%$ with $2 \mathrm{~cm}, 15.5 \%$ with $3 \mathrm{~cm}$ and $5.2 \%$ with $5 \mathrm{~cm}$ margins [95]. The reported local recurrence (LR) rates with width margins varied widely. Monnier et al. reported a LR of $47 \%$ in 66 patients with width margins less than $3 \mathrm{~cm}$ at a mean follow-up of 32 months [96], whereas Farma et al. reported LR of $0.9 \%$ in 206 patients using $2 \mathrm{~cm}$ margins at a follow-up of 64 months [97]. Snow at al recently reported a LR of $1 \%$ and a distal recurrence of $1 \%$ in 98 patients at a follow-up of 53 months [98]. Among them, 44 patients with microscopically incompletely excised DFSP 
were treated with conservative re-excision with a mean width of $1.54 \mathrm{~cm}$, and 54 patients with primary tumors were excised with a mean margin of $2.4 \mathrm{~cm}$ [98]. Harati analyzed 68 patients with DFSP and observed that $2 \mathrm{~cm}$ width margins of normal tissues in primary tumors and in incompletely resected tissues around the scar yielded median negative margins of $0.35 \mathrm{~cm}$ and $0.8 \mathrm{~cm}$ [99], respectively. These data suggest that narrower margins may be good enough to prevent local recurrence. Mullen suggests to choose WLE with a 1.0 to $1.5 \mathrm{~cm}$ safe margins from tumor boundary for most DFSPs on the trunk or extremities since the tumor can be excised in a single stage to achieve excellent cosmetic and functional outcomes, whereas MMS should be selected for relatively small DFSPs in cosmetically sensitive regions including face, scalp (Figure 1B-D) and neck, for best tissue preservation, cosmetic and functional outcomes [89].

Dissection of the tumor bed should be based on the infiltrating depth of the tumor. Deep tumors (Stage IIB) should be excised to include the underlying investing fascia of muscle or pericranium whereas superficial tumors (Stage I + IIA) may be directly excised without dissecting underlying fascia. Since WLE usually requires wide and deep excision from the periphery of the tumor, this makes it difficult to treat the DFSP on digits due to the limited space and the complex structures surrounding the toes and fingers. Mohs surgery may allow tissue sparing for DFSP of the digits, however if tumor extends to periosteum, partial or total amputation of the involved digit will be necessary to obtain tumor-free margins and allows for primary closure with faster return to function [22]. When the patient does not agree with amputation due to concern of functional and cosmetic impairments, tumor can be directly enucleated as demonstrated in Figure 2C,D. The patient needs to be referred to oncologists for further radiation therapy and/or targeted therapy. In surgical practice, selection of which procedure for individual patient must be based on tumor location, size, stage, relationship with surrounding neuro-muscular and bone structures, cosmetic and functional requirements, cost to the patient and the medical resources.

\subsection{Treatment of FS-DFSP}

The FS-DFSP variant is a much more aggressive tumor with local recurrence in more than $50 \%$ of patients and metastasis in $10 \%$ to $15 \%$ of patients [13,100]. FS-DFSP treatment needs consultation with a multidisciplinary specialized soft-tissue sarcoma tumor board [86]. Aggressive treatments for FS-DFSP include adequate WLE with clear surgical margins or MMS (Figure 1B-D). Adjuvant radiotherapy and targeted therapy may be used to reduce the incidence of both local recurrence and metastasis [101].

\subsection{Treatment of Unresectable/Metastatic DFSP}

Unresectable DFSPs include advanced stage tumors, recurrent tumors without any possibility for further resection due to the size and/or location, or tumors in which further resection is likely to cause severe functional or cosmetic defects as shown in Figure $2 \mathrm{C}, \mathrm{D}$, and multiple organ metastases. These tumors should be treated with adjuvant radiation and/or targeted therapy in consultation with a multidisciplinary specialized soft-tissue sarcoma tumor board. Metastatic DFSP may also be treated with single or multiple agent chemotherapy regimens that are used for sarcomas.

\subsubsection{Radiation Therapy}

Multiple studies have shown that DFSP is a radio-responsive tumor and adjuvant radiation therapy is effective to control tumor growth and reduce the incidence of postoperative recurrence [102-106]. A retrospective analysis of 53 DFSP patients treated with surgery and either preoperative or postoperative radiation therapy in the MD Anderson Cancer Center showed disease-free survival rates of $98 \%$ and $93 \%$ at 5 and 10 years, respectively [105]. A total of $60 \mathrm{~Gy}$ for indeterminate or microscopic positive margins and up to $70 \mathrm{~Gy}$ for macroscopic positive margins or primary gross tumor should be given [86,94]. The radiation field should extend $3-5 \mathrm{~cm}$ beyond the surgical margins or primary tumor boundary whenever feasible. An individual dose can be given at 2 Gy daily, 5 times weekly [86,94]. 


\subsubsection{Targeted Therapy}

Imatinib mesylate (IM) is a potent and specific protein tyrosine kinase inhibitor interfering with the phosphorylation and activation of the PDGF receptor $\beta$ which is constitutively activated due to translocation and fusion between PDGFB and COL1A1 genes as discussed in Pathogenesis section. Recent in vitro and in vivo studies demonstrated that IM had growth-inhibitory effects on DFSP $[60,61]$. The effectiveness was evidenced by decreased tumor cellularity and formation of strong hyalinic fibrosis in tissues responded to IM treatment [107]. Treatment with IM in FS-DFSP revealed significant upregulation of the cell-cycle inhibitor $\mathrm{p}_{21}{ }^{\mathrm{Cip} 1}$ and $\beta$-galactosidase (a marker of cellular senescence) but decreased Ki-67 [108]. These data suggest that IM therapy is involved in modulation of tumor cell senescent and proliferative activities. IM may also play a role in immune modulation in tumor tissues. IM treated FS-DFSP tumor tissues compared with untreated tissues exhibited increased infiltration of the CD4 and CD8 T-cells in accompany with increased upregulation of cytokines and chemokines including IL-6, transforming growth factor- $\beta 1$, CXCL- 1, IL- $1 \beta$ and IL- 8 and CD $163^{+} C D 14^{+}$myeloid cells transforming to express CD209 [108]. CD163 ${ }^{+}$macrophages are known to downregulate immune response whereas $\mathrm{CD} 209^{+}$myeloid cells promote T-cell-mediated antitumor responses. These data suggest that IM may exert direct antitumor effects via targeting the PDGFR pathway and indirect antitumor effects via T-cell mediated immune-modulation.

The efficacy of IM was observed in localized and metastatic DFSP with $\mathrm{t}(17 ; 22)$, but not in FS-DFSP lacking $\mathrm{t}(17 ; 22)[39,109-111]$. A systemic review of IM treatment of 152 older patients (mean age: 49.3 years) with locally advanced (mean size: $9.9 \mathrm{~cm}$ in diameter) or metastatic DFSPs revealed $5.2 \%$ of patients with complete response (CR), 55.2\% with partial response (PR), $27.6 \%$ in stable condition (SC) and $9.2 \%$ with progression. There were no differences in response rate using $400-\mathrm{mg}$ or $800-\mathrm{mg}$ daily doses for those with complete or partial responses [112]. A multicenter phase II trial of neoadjuvant IM therapy in advanced primary or locally recurrent DFSP resulted in $7.1 \%$ patients with CR, $50.0 \%$ with PR, 35.7\% with SC and 7.1\% with progression [107].

Further studies showed that IM used as a preoperative adjuvant therapy in DFSP lead to median tumor volume shrinkages from $20 \%$ to $31.5 \%$ [39,107,113,114], which transformed very large, unresectable tumors into resectable ones. Wang et al. reported four of 10 patients with primarily unresectable DFSP received complete surgical resection following IM treatment [38]. These studies provide new treatment options for patients with unresectable, recurrent, advanced and metastatic DFSP.

It should be noted that about $10 \%$ of DFSPs do not respond to IM treatment $[38,107,112,115]$. Some patients initially responding to IM treatment develop secondary resistance to IM rapidly $[115,116]$. Therefore, surgical excision for advanced primary tumor following IM therapy should be performed expeditiously during the "shrinkage window".

The mechanism of resistance to IM is not clear yet. A low PDGFR phosphorylation level observed in IM resistant tumor tissues may not respond to IM $[107,115]$. Sunitinib, with its binding capacity of 10 times greater than that of IM, was demonstrated to be effective in IM resistant DFSP patients $[107,115]$. However, this effect may not be solely due to inhibiting PDFGR since Sunitinib is a multikinase inhibitor targeting not only PDGFR, but also vascular endothelial growth factor receptors 1-3, KIT, colony stimulating factor-1 receptor and FMS-like tyrosine-kinase-3 (FLT3) [117]. Other gene mutations or signal pathways may play a role in IM resistance. Whole-genomic sequencing in a patient with resistance to IM identified 8 nonsynonymous somatic gene mutations, including ACAP2, CARD10, KIAA0556, PAAQR7, PPP1R39, SAFB2, STARD9 and ZFYVE9 [118]. Single nucleotide polymorphism array and sequencing analysis of DFSP105 (an imatinib-resistant human cell line established from a FS-DFSP) showed a localized 9p21 homozygous deletion, encompassing CDKN2A and CDKN2B, which encode $\mathrm{p} 14^{\mathrm{ARF}}, \mathrm{p} 15^{\mathrm{INK} 4 \mathrm{~b}}$ and $\mathrm{p} 16^{\mathrm{INK} 4 \mathrm{a}}$ [119]. p16 inhibits CDK4/6 activity. Loss of p16 expression leads to unrestricted cell cycle progression. Selection of new clonal cells after treatment with either immunotherapy or radiotherapy may also take a part in IM resistant treatment [120].

In the cases of IM resistance, other multikinase inhibitors, including sunitinib [107], sorafenib [121] and pazopanib [122], can be considered since treatment with these inhibitors showed effectiveness in IM 
resistant DFSP patients. In vitro and in vivo studies demonstrated the effectiveness of CDK4/6 inhibitors PD-0332991 and LEE011 in inhibiting DFSP105 proliferation, suggesting that CDK4/6 inhibitors can be potential drugs in p16 negative FS-DFSP [119]. Loss of p16 expression was demonstrated in 2 of 12 classic DFSP and 2 of 6 FS-DFSP [119]. Programmed cell death 1 ligand (PD-L1) expression was detected in metastatic FS-DFSP, but not in the primary tumor, suggesting a role of PD-L1 in the metastasis of FS-DFSP [123]. Since PD-L1 expression in the tumor cells is involved in immune escape from $T$ cell attack [124], PD-L1 signal pathway may be a potential target for metastatic FS-DFSP.

\section{Prognosis and Surveillance}

The prognoses of the patients with DFSP, after surgical resection with negative and sometimes even positive microscopic margins, are generally good. The five- and ten-year recurrence-free survival rates of DFSP are $86 \%$ and $76 \%$ [44], respectively. Increased age, high mitotic index, positive margins and increased cellularity are predictors of poor clinical outcome [43]. Local recurrence is a major concern after surgical excision. The frequencies of local recurrences ranged from $20 \%$ to $50 \%$ [41,44], especially with positive margins. The median time from excision to local recurrence was reported from 32 to 38 months [43,44]. Therefore, mandatory long-term surveillance, at an interval of 6 to 12 months, is recommended [43]. Several studies suggest patients should be reevaluated every 6 months for the first five years and then yearly thereafter $[86,99]$. A thorough history and clinical examination of the primary sites and draining lymph nodes should be performed at each visit. Further imaging examinations should be considered based on patient's tumor's clinical manifestations (size, site, location, rate of growth), surgical procedures and histopathology (presence of high-risk features and margin status). Biopsy should be done on suspected local or distant recurrences or lymph node metastasis.

\section{Conclusions}

DFSP is a low- to intermediate-grade malignancy frequently occurring in the young to middle-aged population. It is histologically characterized by bland spindle cells in a storiform pattern with multiple variants. This needs to be differentiated from other benign and malignant lesions. A vast majority harbor $\mathrm{t}(17 ; 22)$ ( $\mathrm{q} 22$; $\mathrm{q} 13)$ resulting in the formation of COL1A1-PDGFB fusion gene transcript, which holds not only diagnostic value, but also therapeutic significance. WLE with a safe margin should be selected for most DFSPs located on the trunk and extremities. MMS should be considered for relatively small DFSPs in cosmetically sensitive regions to achieve the best tissue preservation with more appealing cosmetic and functional recoveries and can also be used for medium to large DFSP of the trunk and extremities with high cure rates. Subtotal or total digital amputation should be considered for DFSPs located on the digits where complete surgical excision is impractical. Adjuvant therapies-including radiation and targeted therapy-should be chosen for the patients who are unsuitable for surgical excision. Periodic surveillance, at an interval of 6 months in the first five years and then yearly post-excision, is recommended to monitor potential recurrence and metastasis.

Author Contributions: X.H.: study design, literature review, data collection, analysis and interpretation, writing and revising the manuscript. S.D.B., A.T.V., F.W., T.W.S. and G.W.P.: literature review, data collection, analysis and interpretation, manuscript revision. G.M.: study design, literature review, manuscript revision. All authors have read and agreed to the published version of the manuscript.

Funding: This research received no external funding.

Conflicts of Interest: The authors declare no conflict of interest.

\section{References}

1. Hoffmann, E. Über das knollentreibende Fibrosarkomder Haut (Dermatofibrosarkoma protuberans). Dermatology 1925, 43, 1-28. [CrossRef] 
2. Dominguez-Malagon, H.; Valdez-Carrillo Mdel, C.; Cano-Valdez, A.M. Dermatofibroma and dermatofibrosarcoma protuberans: A comparative ultrastructural study. Ultrastruct. Pathol. 2006, 30, 283-291. [CrossRef] [PubMed]

3. Nakamura, I.; Kariya, Y.; Okada, E.; Yasuda, M.; Matori, S.; Ishikawa, O.; Uezato, H.; Takahashi, K. A Novel Chromosomal Translocation Associated With COL1A2-PDGFB Gene Fusion in Dermatofibrosarcoma Protuberans: PDGF Expression as a New Diagnostic Tool. JAMA Dermatol. 2015, 151, 1330-1337. [CrossRef] [PubMed]

4. Pack, G.T.; Tabah, E.J. Dermato-fibrosarcoma protuberans. A report of 39 cases. A.M.A. Arch. Surg. 1951, 62, 391-411. [CrossRef]

5. McPeak, C.J.; Cruz, T.; Nicastri, A.D. Dermatofibrosarcoma protuberans: An analysis of 86 cases-five with metastasis. Ann. Surg. 1967, 166, 803-816. [CrossRef]

6. Smola, M.G.; Soyer, H.P.; Scharnagl, E. Surgical treatment of dermatofibrosarcoma protuberans. A retrospective study of 20 cases with review of literature. Eur. J. Surg. Oncol. 1991, 17, 447-453.

7. Criscione, V.D.; Weinstock, M.A. Descriptive epidemiology of dermatofibrosarcoma protuberans in the United States, 1973 to 2002. J. Am. Acad. Dermatol. 2007, 56, 968-973. [CrossRef]

8. Kreicher, K.L.; Kurlander, D.E.; Gittleman, H.R.; Barnholtz-Sloan, J.S.; Bordeaux, J.S. Incidence and Survival of Primary Dermatofibrosarcoma Protuberans in the United States. Dermatol. Surg. 2016, 42, S24-S31. [CrossRef]

9. Larbcharoensub, N.; Kayankarnnavee, J.; Sanpaphant, S.; Kiranantawat, K.; Wirojtananugoon, C.; Sirikulchayanonta, V. Clinicopathological features of dermatofibrosarcoma protuberans. Oncol. Lett. 2016, 11, 661-667. [CrossRef]

10. Lyu, A.; Wang, Q. Dermatofibrosarcoma protuberans: A clinical analysis. Oncol. Lett. 2018, 16, 1855-1862. [CrossRef] [PubMed]

11. Valdivielso-Ramos, M.; Hernanz, J.M. Dermatofibrosarcoma protuberans in childhood. Actas Dermo-Sifiliogr. 2012, 103, 863-873. [CrossRef]

12. Kornik, R.I.; Muchard, L.K.; Teng, J.M. Dermatofibrosarcoma protuberans in children: An update on the diagnosis and treatment. Pediatric Dermatol. 2012, 29, 707-713. [CrossRef] [PubMed]

13. Mentzel, T.; Beham, A.; Katenkamp, D.; Dei Tos, A.P.; Fletcher, C.D. Fibrosarcomatous ("high-grade") dermatofibrosarcoma protuberans: Clinicopathologic and immunohistochemical study of a series of 41 cases with emphasis on prognostic significance. Am. J. Surg. Pathol. 1998, 22, 576-587. [CrossRef] [PubMed]

14. Simon, M.P.; Pedeutour, F.; Sirvent, N.; Grosgeorge, J.; Minoletti, F.; Coindre, J.M.; Terrier-Lacombe, M.J.; Mandahl, N.; Craver, R.D.; Blin, N.; et al. Deregulation of the platelet-derived growth factor B-chain gene via fusion with collagen gene COL1A1 in dermatofibrosarcoma protuberans and giant-cell fibroblastoma. Nat. Genet 1997, 15, 95-98. [CrossRef] [PubMed]

15. Sirvent, N.; Maire, G.; Pedeutour, F. Genetics of dermatofibrosarcoma protuberans family of tumors: From ring chromosomes to tyrosine kinase inhibitor treatment. Genes Chromosom. Cancer 2003, 37, 1-19. [CrossRef] [PubMed]

16. Bianchini, L.; Maire, G.; Guillot, B.; Joujoux, J.M.; Follana, P.; Simon, M.P.; Coindre, J.M.; Pedeutour, F. Complex $\mathrm{t}(5 ; 8)$ involving the CSPG2 and PTK2B genes in a case of dermatofibrosarcoma protuberans without the COL1A1-PDGFB fusion. Virchows Arch. Int. J. Pathol. 2008, 452, 689-696. [CrossRef] [PubMed]

17. Takahira, T.; Oda, Y.; Tamiya, S.; Yamamoto, H.; Kawaguchi, K.; Kobayashi, C.; Oda, S.; Iwamoto, Y.; Tsuneyoshi, M. Microsatellite instability and p53 mutation associated with tumor progression in dermatofibrosarcoma protuberans. Hum. Pathol. 2004, 35, 240-245. [CrossRef]

18. Heldin, C.H.; Westermark, B. Mechanism of action and in vivo role of platelet-derived growth factor. Physiol. Rev. 1999, 79, 1283-1316. [CrossRef]

19. Jones, A.V.; Cross, N.C. Oncogenic derivatives of platelet-derived growth factor receptors. Cell. Mol. Life Sci. 2004, 61, 2912-2923. [CrossRef] [PubMed]

20. Andrae, J.; Gallini, R.; Betsholtz, C. Role of platelet-derived growth factors in physiology and medicine. Genome Res. 2008, 22, 1276-1312. [CrossRef] [PubMed]

21. Hiraki-Hotokebuchi, Y.; Yamada, Y.; Kohashi, K.; Yamamoto, H.; Endo, M.; Setsu, N.; Yuki, K.; Ito, T.; Iwamoto, Y.; Furue, M.; et al. Alteration of PDGFRbeta-Akt-mTOR pathway signaling in fibrosarcomatous transformation of dermatofibrosarcoma protuberans. Hum. Pathol. 2017, 67, 60-68. [CrossRef] 
22. Shah, K.K.; McHugh, J.B.; Folpe, A.L.; Patel, R.M. Dermatofibrosarcoma Protuberans of Distal Extremities and Acral Sites: A Clinicopathologic Analysis of 27 Cases. Am. J. Surg. Pathol. 2018, 42, 413-419. [CrossRef] [PubMed]

23. Takahira, T.; Oda, Y.; Tamiya, S.; Higaki, K.; Yamamoto, H.; Kobayashi, C.; Izumi, T.; Tateishi, N.; Iwamoto, Y.; Tsuneyoshi, M. Detection of COL1A1-PDGFB fusion transcripts and PDGFB/PDGFRB mRNA expression in dermatofibrosarcoma protuberans. Mod. Pathol. 2007, 20, 668-675. [CrossRef] [PubMed]

24. Kutzner, H.; Mentzel, T.; Palmedo, G.; Hantschke, M.; Rutten, A.; Paredes, B.E.; Scharer, L.; Guillen, C.S.; Requena, L. Plaque-like CD34-positive dermal fibroma ("medallion-like dermal dendrocyte hamartoma"): Clinicopathologic, immunohistochemical, and molecular analysis of 5 cases emphasizing its distinction from superficial, plaque-like dermatofibrosarcoma protuberans. Am. J. Surg. Pathol. 2010, 34, 190-201. [CrossRef] [PubMed]

25. Dickson, B.C.; Hornick, J.L.; Fletcher, C.D.M.; Demicco, E.G.; Howarth, D.J.; Swanson, D.; Zhang, L.; Sung, Y.S.; Antonescu, C.R. Dermatofibrosarcoma protuberans with a novel COL6A3-PDGFD fusion gene and apparent predilection for breast. Genes Chromosom. Cancer 2018, 57, 437-445. [CrossRef]

26. Dadone-Montaudie, B.; Alberti, L.; Duc, A.; Delespaul, L.; Lesluyes, T.; Perot, G.; Lancon, A.; Paindavoine, S.; Di Mauro, I.; Blay, J.Y.; et al. Alternative PDGFD rearrangements in dermatofibrosarcomas protuberans without PDGFB fusions. Mod. Pathol. 2018, 31, 1683-1693. [CrossRef]

27. Hisaoka, M.; Okamoto, S.; Morimitsu, Y.; Tsuji, S.; Hashimoto, H. Dermatofibrosarcoma protuberans with fibrosarcomatous areas. Molecular abnormalities of the p53 pathway in fibrosarcomatous transformation of dermatofibrosarcoma protuberans. Virchows Archiv 1998, 433, 323-329. [CrossRef]

28. Yong, P.F.; Grosse-Kreul, D.; Maher, J.; Salisbury, J.R.; Ibrahim, M.A. Dermatofibrosarcoma protuberans in a patient with X-linked agammaglobulinaemia. J. Clin. Pathol. 2007, 60, 1162-1164. [CrossRef]

29. Kesserwan, C.; Sokolic, R.; Cowen, E.W.; Garabedian, E.; Heselmeyer-Haddad, K.; Lee, C.C.; Pittaluga, S.; Ortiz, C.; Baird, K.; Lopez-Terrada, D.; et al. Multicentric dermatofibrosarcoma protuberans in patients with adenosine deaminase-deficient severe combined immune deficiency. J. Allergy Clin. Immunol. 2012, 129, 762-769.e761. [CrossRef]

30. Duffy, R.; Liaqat, M.; Lawrence, N.; Manders, S. Dermatofibrosarcoma protuberans in a pediatric patient with ataxia telangiectasia syndrome. Pediatric Dermatol. 2019, 36, 400-401. [CrossRef]

31. Sapadin, A.N.; Gelfand, J.M.; Howe, K.L.; Phelps, R.G.; Grand, D.; Rudikoff, D. Dermatofibrosarcoma protuberans in two patients with acquired immunodeficiency syndrome. Cutis 2000, 65, 85-88. [PubMed]

32. Anderson, K.A.; Vidimos, A.T. Two primary dermatofibrosarcoma protuberans associated with different pregnancies in a single patient. Dermatol. Surg. 2012, 38, 1876-1878. [CrossRef] [PubMed]

33. Hanabusa, M.; Kamo, R.; Harada, T.; Ishii, M. Dermatofibrosarcoma protuberans with atrophic appearance at early stage of the tumor. J. Dermatol. 2007, 34, 336-339. [CrossRef] [PubMed]

34. Makino, M.; Sasaoka, S.; Nakanishi, G.; Makino, E.; Fujimoto, W. Congenital atrophic dermatofibrosarcoma protuberans detected by COL1A1-PDGFB rearrangement. Diagn. Pathol. 2016, 11, 24. [CrossRef]

35. Martin, L.; Combemale, P.; Dupin, M.; Chouvet, B.; Kanitakis, J.; Bouyssou-Gauthier, M.L.; Dubreuil, G.; Claudy, A.; Grimand, P.S. The atrophic variant of dermatofibrosarcoma protuberans in childhood: A report of six cases. Br. J. Dermatol. 1998, 139, 719-725.

36. Laske, J.; Sergon, M.; Mentzel, T.; Beissert, S.; Maschke, J. Congenital dermatofibrosarcoma protuberans clinically mimicking a melanocytic naevus treated with serial excisions. JEADV 2017, 31, e541-e542. [CrossRef]

37. Wrotnowski, U.; Cooper, P.H.; Shmookler, B.M. Fibrosarcomatous change in dermatofibrosarcoma protuberans. Am. J. Surg. Pathol. 1988, 12, 287-293. [CrossRef]

38. Wang, C.; Luo, Z.; Chen, J.; Zheng, B.; Zhang, R.; Chen, Y.; Shi, Y. Target therapy of unresectable or metastatic dermatofibrosarcoma protuberans with imatinib mesylate: An analysis on 22 Chinese patients. Medicine 2015, 94, e773. [CrossRef]

39. Rutkowski, P.; Klimczak, A.; Lugowska, I.; Jagielska, B.; Wagrodzki, M.; Debiec-Rychter, M.; Pienkowska-Grela, B.; Switaj, T. Long-term results of treatment of advanced dermatofibrosarcoma protuberans (DFSP) with imatinib mesylate-The impact of fibrosarcomatous transformation. Eur. J. Surg. Oncol. (EJSO) 2017, 43, 1134-1141. [CrossRef]

40. Chilukuri, D.S.; Premkumar, P.; Venkitaraman, B.; Soundararajan, J.C.B. Pancreatic metastasis of dermatofibrosarcoma protuberans: A rare case. BMJ Case Rep. 2020, 13. [CrossRef] 
41. Fiore, M.; Miceli, R.; Mussi, C.; Lo Vullo, S.; Mariani, L.; Lozza, L.; Collini, P.; Olmi, P.; Casali, P.G.; Gronchi, A. Dermatofibrosarcoma protuberans treated at a single institution: A surgical disease with a high cure rate. J. Clin. Oncol. 2005, 23, 7669-7675. [CrossRef] [PubMed]

42. Li, Y.; Wang, C.; Xiang, B.; Chen, S.; Li, L.; Ji, Y. Clinical Features, Pathological Findings and Treatment of Recurrent Dermatofibrosarcoma Protuberans. J. Cancer 2017, 8, 1319-1323. [CrossRef]

43. Bowne, W.B.; Antonescu, C.R.; Leung, D.H.; Katz, S.C.; Hawkins, W.G.; Woodruff, J.M.; Brennan, M.F.; Lewis, J.J. Dermatofibrosarcoma protuberans: A clinicopathologic analysis of patients treated and followed at a single institution. Cancer 2000, 88, 2711-2720. [CrossRef]

44. Chang, C.K.; Jacobs, I.A.; Salti, G.I. Outcomes of surgery for dermatofibrosarcoma protuberans. Eur. J. Surg. Oncol. (EJSO) 2004, 30, 341-345. [CrossRef] [PubMed]

45. Gloster, H.M., Jr. Dermatofibrosarcoma protuberans. J. Am. Acad. Dermatol. 1996, 35, 355-374. [CrossRef]

46. LeBlanc, J.; Chan, C.; Zedlitz, A. Dermatofibrosarcoma protuberans. Cutis 2017, 100, E6-E7.

47. Behfar, K.N.; Mendeszoon, M.J.; Chrzan, J.S.; Habershaw, G.M. Dermatofibrosarcoma protuberans of the hallux. J. Am. Acad. Dermatol. 1996, 86, 126-128. [CrossRef]

48. Assassa, G.S.; Siegel, M.E.; Chen, D.C.; Ansari, A.N. Dermatofibrosarcoma protuberans of the toe. Findings on multiple imaging modalities. Clin. Nucl. Med. 1993, 18, 978-980. [CrossRef]

49. Madden, C.; Spector, A.; Siddiqui, S.; Mirkin, G.; Yim, J.; Hao, X. Dermatofibrosarcoma Protuberans on Adult Toes: A Case Report and Review of the Literature. Anticancer. Res. 2019, 39, 2105-2111. [CrossRef]

50. Nelson, T.G.; Gonda, P.; Sheppard, P.; Keohane, S. Dermatofibrosarcoma Protuberans of the Scalp: A Challenging Tumor with a Proposed Modification to the Slow Mohs Technique. Dermatol. Surg. 2019. [CrossRef]

51. Bouhani, M.; Fertani, Y.; Zemni, I.; Adouni, O.; Bouida, A.; Chargui, R.; Khaled, R. Dermatofibrosarcoma Protuberans of the Breast in Man: An Extremely Rare Entity With a Review of the Literature. J. Investig. Med. High Impact Case Rep. 2019, 7. [CrossRef] [PubMed]

52. Vecchio, G.M.; Broggi, G.; Mule, A.; Piombino, E.; Magro, G. Dermatofibrosarcoma protuberans: A tumor in the wide spectrum of the bland-looking spindle cell lesions of the breast. Pathologica 2019, 111, 87-91. [CrossRef]

53. Kahn, T.A.; Liranzo, M.O.; Vidimos, A.T.; Papay, F.A.; Bergfeld, W.F. Pathological case of the month. Congenital dermatofibrosarcoma protuberans. Arch. Pediatr. Adolesc. Med. 1996, 150, 549-550. [CrossRef] [PubMed]

54. Edelweiss, M.; Malpica, A. Dermatofibrosarcoma protuberans of the vulva: A clinicopathologic and immunohistochemical study of 13 cases. Am. J. Surg. Pathol. 2010, 34, 393-400. [CrossRef] [PubMed]

55. Thornton, S.L.; Reid, J.; Papay, F.A.; Vidimos, A.T. Childhood dermatofibrosarcoma protuberans: Role of preoperative imaging. J. Am. Acad. Dermatol. 2005, 53, 76-83. [CrossRef]

56. Riggs, K.; McGuigan, K.L.; Morrison, W.B.; Samie, F.H.; Humphreys, T. Role of magnetic resonance imaging in perioperative assessment of dermatofibrosarcoma protuberans. Dermatol. Surg. 2009, 35, 2036-2041. [CrossRef]

57. Zhang, L.; Liu, Q.Y.; Cao, Y.; Zhong, J.S.; Zhang, W.D. Dermatofibrosarcoma Protuberans: Computed Tomography and Magnetic Resonance Imaging Findings. Medicine 2015, 94, e1001. [CrossRef]

58. Torreggiani, W.C.; Al-Ismail, K.; Munk, P.L.; Nicolaou, S.; O'Connell, J.X.; Knowling, M.A. Dermatofibrosarcoma protuberans: MR imaging features. Am. J. Roentgenol. 2002, 178, 989-993. [CrossRef]

59. Lee, M.H.; Kim, N.R.; Ryu, J.A. Cyst-like solid tumors of the musculoskeletal system: An analysis of ultrasound findings. Skelet. Radiol. 2010, 39, 981-986. [CrossRef]

60. Rodriguez Bandera, A.I.; Moreno Bonilla, G.; Feito Rodriguez, M.; Beato Merino, M.J.; de Lucas Laguna, R. Jellyfish-like sonographic pattern can help recognition of dermatofibrosarcoma protuberans. Report of 3 new cases and review of the literature. Australas. J. Dermatol. 2019, 60, e148-e150. [CrossRef]

61. Kransdorf, M.J.; Meis-Kindblom, J.M. Dermatofibrosarcoma protuberans: Radiologic appearance. Am. J. Roentgenol. 1994, 163, 391-394. [CrossRef] [PubMed]

62. Kashyap, R.; Muddu, V.K.; Anantamakula, S.; Sri, S. Usefulness of (18)F-fluorodeoxyglucose positron emission tomography/computed tomography in dermatofibrosarcoma protuberans on treatment with imatinib. IJNM 2016, 31, 191-193. [CrossRef] [PubMed] 
63. Suman, S.; Sharma, P.; Jain, T.K.; Sahoo, M.K.; Bal, C.; Kumar, R. Recurrent dermatofibrosarcoma protuberans with pulmonary metastases presenting twelve years after initial diagnosis: 18F-FDG PET/CT imaging findings. Clin. Nucl. Med. 2014, 39, 77-78. [CrossRef]

64. Bague, S.; Folpe, A.L. Dermatofibrosarcoma protuberans presenting as a subcutaneous mass: A clinicopathological study of 15 cases with exclusive or near-exclusive subcutaneous involvement. Am. J. Dermatopathol. 2008, 30, 327-332. [CrossRef] [PubMed]

65. Llombart, B.; Monteagudo, C.; Sanmartin, O.; Lopez-Guerrero, J.A.; Serra-Guillen, C.; Poveda, A.; Jorda, E.; Fernandez-Serra, A.; Pellin, A.; Guillen, C.; et al. Dermatofibrosarcoma protuberans: A clinicopathological, immunohistochemical, genetic (COL1A1-PDGFB), and therapeutic study of low-grade versus high-grade (fibrosarcomatous) tumors. J. Am. Acad. Dermatol. 2011, 65, 564-575. [CrossRef]

66. Liang, C.A.; Jambusaria-Pahlajani, A.; Karia, P.S.; Elenitsas, R.; Zhang, P.D.; Schmults, C.D. A systematic review of outcome data for dermatofibrosarcoma protuberans with and without fibrosarcomatous change. J. Am. Acad. Dermatol. 2014, 71, 781-786. [CrossRef]

67. Lemm, D.; Mugge, L.O.; Mentzel, T.; Hoffken, K. Current treatment options in dermatofibrosarcoma protuberans. J. Cancer Res. Clin. Oncol. 2009, 135, 653-665. [CrossRef]

68. Huis In 't Veld, E.A.; van Coevorden, F.; Grunhagen, D.J.; Smith, M.J.; van Akkooi, A.C.J.; Wouters, M.; Hayes, A.J.; Verhoef, C.; Strauss, D.C.; van Houdt, W.J. Outcome after surgical treatment of dermatofibrosarcoma protuberans: Is clinical follow-up always indicated? Cancer 2019, 125, 735-741. [CrossRef]

69. Fletcher, C.D.; Theaker, J.M.; Flanagan, A.; Krausz, T. Pigmented dermatofibrosarcoma protuberans (Bednar tumour): Melanocytic colonization or neuroectodermal differentiation? A clinicopathological and immunohistochemical study. Histopathology 1988, 13, 631-643. [CrossRef]

70. Terrier-Lacombe, M.J.; Guillou, L.; Maire, G.; Terrier, P.; Vince, D.R.; de Saint Aubain Somerhausen, N.; Collin, F.; Pedeutour, F.; Coindre, J.M. Dermatofibrosarcoma protuberans, giant cell fibroblastoma, and hybrid lesions in children: Clinicopathologic comparative analysis of 28 cases with molecular data-a study from the French Federation of Cancer Centers Sarcoma Group. Am. J. Surg. Pathol. 2003, 27, 27-39. [CrossRef]

71. Jha, P.; Moosavi, C.; Fanburg-Smith, J.C. Giant cell fibroblastoma: An update and addition of 86 new cases from the Armed Forces Institute of Pathology, in honor of Dr. Franz, M. Enzinger. Ann. Diagn. Pathol. 2007, 11, 81-88. [CrossRef] [PubMed]

72. Craver, R.D.; Correa, H.; Kao, Y.S.; Van Brunt, T.; Golladay, E.S. Aggressive giant cell fibroblastoma with a balanced 17;22 translocation. Cancer Genet. Cytogenet. 1995, 80, 20-22. [CrossRef]

73. Dal Cin, P.; Sciot, R.; de Wever, I.; Brock, P.; Casteels-Van Daele, M.; Van Damme, B.; Van Den Berghe, H. Cytogenetic and immunohistochemical evidence that giant cell fibroblastoma is related to dermatofibrosarcoma protuberans. Genes Chromosomes Cancer 1996, 15, 73-75. [CrossRef]

74. O'Brien, K.P.; Seroussi, E.; Dal Cin, P.; Sciot, R.; Mandahl, N.; Fletcher, J.A.; Turc-Carel, C.; Dumanski, J.P. Various regions within the alpha-helical domain of the COL1A1 gene are fused to the second exon of the PDGFB gene in dermatofibrosarcomas and giant-cell fibroblastomas. Genes Chromosomes Cancer 1998, 23, 187-193.

75. Harvell, J.D.; Kilpatrick, S.E.; White, W.L. Histogenetic relations between giant cell fibroblastoma and dermatofibrosarcoma protuberans. CD34 staining showing the spectrum and a simulator. Am. J. Dermatopathol. 1998, 20, 339-345. [CrossRef] [PubMed]

76. Braswell, D.S.; Ayoubi, N.; Motaparthi, K.; Walker, A. Dermatofibrosarcoma protuberans with features of giant cell fibroblastoma in an adult. J. Cutan. Pathol. 2020, 47, 317-320. [CrossRef]

77. Maire, G.; Pedeutour, F.; Coindre, J.M. COL1A1-PDGFB gene fusion demonstrates a common histogenetic origin for dermatofibrosarcoma protuberans and its granular cell variant. Am. J. Surg. Pathol. 2002, 26, 932-937. [CrossRef]

78. Sabater-Marco, V.; Perez-Valles, A.; Berzal-Cantalejo, F.; Rodriguez-Serna, M.; Martinez-Diaz, F.; Martorell-Cebollada, M. Sclerosing dermatofibrosarcoma protuberans (DFSP): An unusual variant with focus on the histopathologic differential diagnosis. Int. J. Dermatol. 2006, 45, 59-62. [CrossRef]

79. Walluks, K.; Chen, Y.; Woelfel, C.; Yang, L.; Cui, T.; Seliger, C.; Geier, C.; Knosel, T.; Hauke, S.; Petersen, I. Molecular and clinicopathological analysis of dermatofibrosarcoma protuberans. Pathol. Res. Prac. 2013, 209, 30-35. [CrossRef] 
80. Han, T.Y.; Chang, H.S.; Lee, J.H.; Lee, W.M.; Son, S.J. A clinical and histopathological study of 122 cases of dermatofibroma (benign fibrous histiocytoma). Ann. Dermatol. 2011, 23, 185-192. [CrossRef]

81. Hao, X.; Levine, D.; Yim, J.; Qi, C.; Firestone, L.; Beiser, I.; Leone, E.; Woelffer, K.; Mirkin, G. Schwannoma of Foot and Ankle: Seven Case Reports and Literature Review. Anticancer Res. 2019, 39, 5185-5194. [CrossRef] [PubMed]

82. Ortonne, N.; Wolkenstein, P.; Blakeley, J.O.; Korf, B.; Plotkin, S.R.; Riccardi, V.M.; Miller, D.C.; Huson, S.; Peltonen, J.; Rosenberg, A.; et al. Cutaneous neurofibromas: Current clinical and pathologic issues. Neurology 2018, 91, S5-S13. [CrossRef] [PubMed]

83. Yoshida, A.; Tsuta, K.; Ohno, M.; Yoshida, M.; Narita, Y.; Kawai, A.; Asamura, H.; Kushima, R. STAT6 immunohistochemistry is helpful in the diagnosis of solitary fibrous tumors. Am. J. Surg. Pathol. 2014, 38, 552-559. [CrossRef]

84. Sachdeva, M.P.; Goldblum, J.R.; Rubin, B.P.; Billings, S.D. Low-fat and fat-free pleomorphic lipomas: A diagnostic challenge. Am. J. Dermatopathol. 2009, 31, 423-426. [CrossRef] [PubMed]

85. Nicolson, N.G.; Han, D. Desmoplastic melanoma. J. Surg. Oncol. 2019, 119, 208-215. [CrossRef] [PubMed]

86. Saiag, P.; Grob, J.J.; Lebbe, C.; Malvehy, J.; del Marmol, V.; Pehamberger, H.; Peris, K.; Stratigos, A.; Middelton, M.; Basholt, L.; et al. Diagnosis and treatment of dermatofibrosarcoma protuberans. European consensus-based interdisciplinary guideline. Eur. J. Cancer 2015, 51, 2604-2608. [CrossRef] [PubMed]

87. Meguerditchian, A.N.; Wang, J.; Lema, B.; Kraybill, W.G.; Zeitouni, N.C.; Kane, J.M., 3rd. Wide excision or Mohs micrographic surgery for the treatment of primary dermatofibrosarcoma protuberans. Am. J. Clin. Oncol. 2010, 33, 300-303. [CrossRef]

88. Paradisi, A.; Abeni, D.; Rusciani, A.; Cigna, E.; Wolter, M.; Scuderi, N.; Rusciani, L.; Kaufmann, R.; Podda, M. Dermatofibrosarcoma protuberans: Wide local excision vs. Mohs micrographic surgery. Cancer Treat. Rev. 2008, 34, 728-736. [CrossRef]

89. Mullen, J.T. Dermatofibrosarcoma Protuberans: Wide Local Excision Versus Mohs Micrographic Surgery. Surg. Oncol. Clin. N. Am. 2016, 25, 827-839. [CrossRef] [PubMed]

90. Lowe, G.C.; Onajin, O.; Baum, C.L.; Otley, C.C.; Arpey, C.J.; Roenigk, R.K.; Brewer, J.D. A Comparison of Mohs Micrographic Surgery and Wide Local Excision for Treatment of Dermatofibrosarcoma Protuberans With Long-Term Follow-up: The Mayo Clinic Experience. Dermatol. Surg. 2017, 43, 98-106. [CrossRef] [PubMed]

91. Loghdey, M.S.; Varma, S.; Rajpara, S.M.; Al-Rawi, H.; Perks, G.; Perkins, W. Mohs micrographic surgery for dermatofibrosarcoma protuberans (DFSP): A single-centre series of 76 patients treated by frozen-section Mohs micrographic surgery with a review of the literature. J. Plast. Reconstr. Aesthetic Surg. 2014, 67, 1315-1321. [CrossRef]

92. Malan, M.; Xuejingzi, W.; Quan, S.J. The efficacy of Mohs micrographic surgery over the traditional wide local excision surgery in the cure of dermatofibrosarcoma protuberans. Pan Afr. Med. J. 2019, 33, 297. [CrossRef] [PubMed]

93. Foshee, J.P.; Trofymenko, O.; Zeitouni, N.C. Surgical and Functional Considerations of Dermatofibrosarcoma Protuberans Involving Facial Nerve Danger Zones. J. Clin. Aesthetic Dermatol. 2019, 12, 39-43.

94. Schmults, C.D.; Rachael Blitzblau, R.; Engh, A. NCCN Clinical Practice Guidelines in Oncology (NCCN Guidelinesß) for Dermatofibrosarcoma Protuberans (Version 1.2020). (C) 2020 National Comprehensive Cancer Network, Inc.: Plymouth Meeting, PA, USA, 2019; Available

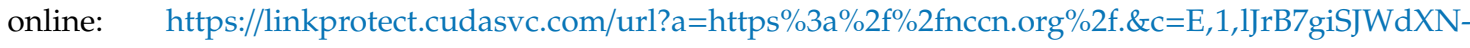
pBdcIkXYoOYTQT0hj26oGKyiktT0uURv6PjKeYKsXBoaccaaWH9_3DfJ4mTTuFEqjURd_xXSQeEa9TvWhbUrXhl5T7fw, \&typo=1 (accessed on 1 June 2020).

95. Ratner, D.; Thomas, C.O.; Johnson, T.M.; Sondak, V.K.; Hamilton, T.A.; Nelson, B.R.; Swanson, N.A.; Garcia, C.; Clark, R.E.; Grande, D.J. Mohs micrographic surgery for the treatment of dermatofibrosarcoma protuberans. Results of a multiinstitutional series with an analysis of the extent of microscopic spread. J. Am. Acad. Dermatol. 1997, 37, 600-613. [CrossRef]

96. Monnier, D.; Vidal, C.; Martin, L.; Danzon, A.; Pelletier, F.; Puzenat, E.; Algros, M.P.; Blanc, D.; Laurent, R.; Humbert, P.H.; et al. Dermatofibrosarcoma protuberans: A population-based cancer registry descriptive study of 66 consecutive cases diagnosed between 1982 and 2002. J. Eur. Acad. Dermatol. Venereol. 2006, 20, 1237-1242. [CrossRef] [PubMed] 
97. Farma, J.M.; Ammori, J.B.; Zager, J.S.; Marzban, S.S.; Bui, M.M.; Bichakjian, C.K.; Johnson, T.M.; Lowe, L.; Sabel, M.S.; Wong, S.L.; et al. Dermatofibrosarcoma protuberans: How wide should we resect? Ann. Surg. Oncol. 2010, 17, 2112-2118. [CrossRef]

98. Snow, H.; Davies, E.; Strauss, D.C.; Smith, M.; Hayes, A.J. Conservative Re-excision is a Safe and Simple Alternative to Radical Resection in Revision Surgery for Dermatofibrosarcoma Protuberans. Ann. Surg. Oncol. 2020, 27, 919-923. [CrossRef]

99. Harati, K.; Lange, K.; Goertz, O.; Lahmer, A.; Kapalschinski, N.; Stricker, I.; Lehnhardt, M.; Daigeler, A. A single-institutional review of 68 patients with dermatofibrosarcoma protuberans: Wide re-excision after inadequate previous surgery results in a high rate of local control. World J. Surg. Oncol. 2017, 15, 5. [CrossRef]

100. Abbott, J.J.; Oliveira, A.M.; Nascimento, A.G. The prognostic significance of fibrosarcomatous transformation in dermatofibrosarcoma protuberans. Am. J. Surg. Pathol. 2006, 30, 436-443. [CrossRef]

101. Goldblum, J.R.; Reith, J.D.; Weiss, S.W. Sarcomas arising in dermatofibrosarcoma protuberans: A reappraisal of biologic behavior in eighteen cases treated by wide local excision with extended clinical follow up. Am. J. Surg. Pathol. 2000, 24, 1125-1130. [CrossRef]

102. Williams, N.; Morris, C.G.; Kirwan, J.M.; Dagan, R.; Mendenhall, W.M. Radiotherapy for dermatofibrosarcoma protuberans. Am. J. Clin. Oncol. 2014, 37, 430-432. [CrossRef]

103. Ballo, M.T.; Zagars, G.K.; Pisters, P.; Pollack, A. The role of radiation therapy in the management of dermatofibrosarcoma protuberans. Int. J. Radiat. Oncol. 1998, 40, 823-827. [CrossRef]

104. Dagan, R.; Morris, C.G.; Zlotecki, R.A.; Scarborough, M.T.; Mendenhall, W.M. Radiotherapy in the treatment of dermatofibrosarcoma protuberans. Am. J. Clin. Oncol. 2005, 28, 537-539. [CrossRef]

105. Castle, K.O.; Guadagnolo, B.A.; Tsai, C.J.; Feig, B.W.; Zagars, G.K. Dermatofibrosarcoma protuberans: Long-term outcomes of 53 patients treated with conservative surgery and radiation therapy. Int. J. Radiat. Oncol. 2013, 86, 585-590. [CrossRef] [PubMed]

106. Agyeman, M.B.; Vanderpuye, V.D.; Yarney, J. Abscopal Effect of Radiotherapy in Imatinib-resistant Dermatofibrosarcoma Protuberans. Cureus 2019, 11, e3857. [CrossRef]

107. Ugurel, S.; Mentzel, T.; Utikal, J.; Helmbold, P.; Mohr, P.; Pfohler, C.; Schiller, M.; Hauschild, A.; Hein, R.; Kampgen, E.; et al. Neoadjuvant imatinib in advanced primary or locally recurrent dermatofibrosarcoma protuberans: A multicenter phase II DeCOG trial with long-term follow-up. Clin. Cancer Res. 2014, 20, 499-510. [CrossRef]

108. Tazzari, M.; Indio, V.; Vergani, B.; De Cecco, L.; Rini, F.; Negri, T.; Camisaschi, C.; Fiore, M.; Stacchiotti, S.; Dagrada, G.P.; et al. Adaptive Immunity in Fibrosarcomatous Dermatofibrosarcoma Protuberans and Response to Imatinib Treatment. J. Investig. Dermatol. 2017, 137, 484-493. [CrossRef] [PubMed]

109. McArthur, G.A. Molecular targeting of dermatofibrosarcoma protuberans: A new approach to a surgical disease. J. Natl. Compr. Cancer Netw. 2007, 5, 557-562. [CrossRef] [PubMed]

110. Stacchiotti, S.; Pantaleo, M.A.; Negri, T.; Astolfi, A.; Tazzari, M.; Dagrada, G.P.; Urbini, M.; Indio, V.; Maestro, R.; Gronchi, A.; et al. Efficacy and Biological Activity of Imatinib in Metastatic Dermatofibrosarcoma Protuberans (DFSP). Clin. Cancer Res. 2016, 22, 837-846. [CrossRef] [PubMed]

111. Rutkowski, P.; Van Glabbeke, M.; Rankin, C.J.; Ruka, W.; Rubin, B.P.; Debiec-Rychter, M.; Lazar, A.; Gelderblom, H.; Sciot, R.; Lopez-Terrada, D.; et al. Imatinib mesylate in advanced dermatofibrosarcoma protuberans: Pooled analysis of two phase II clinical trials. J. Clin. Oncol. 2010, 28, 1772-1779. [CrossRef] [PubMed]

112. Navarrete-Dechent, C.; Mori, S.; Barker, C.A.; Dickson, M.A.; Nehal, K.S. Imatinib Treatment for Locally Advanced or Metastatic Dermatofibrosarcoma Protuberans: A Systematic Review. JAMA Dermatol. 2019, 155, 361-369. [CrossRef]

113. Kerob, D.; Porcher, R.; Verola, O.; Dalle, S.; Maubec, E.; Aubin, F.; D’Incan, M.; Bodokh, I.; Boulinguez, S.; Madelaine-Chambrin, I.; et al. Imatinib mesylate as a preoperative therapy in dermatofibrosarcoma: Results of a multicenter phase II study on 25 patients. Clin. Cancer Res. 2010, 16, 3288-3295. [CrossRef] [PubMed]

114. Wang, J.; Yin, Y.; Shen, C.; Yin, X.; Cai, Z.; Pu, L.; Fu, W.; Wang, Y.; Zhang, B. Preoperative imatinib treatment in patients with locally advanced and metastatic/recurrent gastrointestinal stromal tumors: A single-center analysis. Medicine 2020, 99, e19275. [CrossRef] [PubMed]

115. Stacchiotti, S.; Pedeutour, F.; Negri, T.; Conca, E.; Marrari, A.; Palassini, E.; Collini, P.; Keslair, F.; Morosi, C.; Gronchi, A.; et al. Dermatofibrosarcoma protuberans-derived fibrosarcoma: Clinical history, biological profile and sensitivity to imatinib. Int. J. Cancer 2011, 129, 1761-1772. [CrossRef] [PubMed] 
116. McArthur, G.A.; Demetri, G.D.; van Oosterom, A.; Heinrich, M.C.; Debiec-Rychter, M.; Corless, C.L.; Nikolova, Z.; Dimitrijevic, S.; Fletcher, J.A. Molecular and clinical analysis of locally advanced dermatofibrosarcoma protuberans treated with imatinib: Imatinib Target Exploration Consortium Study B2225. J. Clin. Oncol. 2005, 23, 866-873. [CrossRef]

117. Kitagawa, D.; Yokota, K.; Gouda, M.; Narumi, Y.; Ohmoto, H.; Nishiwaki, E.; Akita, K.; Kirii, Y. Activity-based kinase profiling of approved tyrosine kinase inhibitors. Genes Cells 2013, 18, 110-122. [CrossRef] [PubMed]

118. Hong, J.Y.; Liu, X.; Mao, M.; Li, M.; Choi, D.I.; Kang, S.W.; Lee, J.; La Choi, Y. Genetic aberrations in imatinib-resistant dermatofibrosarcoma protuberans revealed by whole genome sequencing. PLoS ONE 2013, 8, e69752. [CrossRef]

119. Eilers, G.; Czaplinski, J.T.; Mayeda, M.; Bahri, N.; Tao, D.; Zhu, M.; Hornick, J.L.; Lindeman, N.I.; Sicinska, E.; Wagner, A.J.; et al. CDKN2A/p16 Loss Implicates CDK4 as a Therapeutic Target in Imatinib-Resistant Dermatofibrosarcoma Protuberans. Mol. Cancer Ther. 2015, 14, 1346-1353. [CrossRef]

120. Oh, E.; Jeong, H.M.; Kwon, M.J.; Ha, S.Y.; Park, H.K.; Song, J.Y.; Kim, Y.J.; Choi, J.S.; Lee, E.H.; Lee, J.; et al. Unforeseen clonal evolution of tumor cell population in recurrent and metastatic dermatofibrosarcoma protuberans. PLOS ONE 2017, 12, e0185826. [CrossRef]

121. Kamar, F.G.; Kairouz, V.F.; Sabri, A.N. Dermatofibrosarcoma protuberans (DFSP) successfully treated with sorafenib: Case report. Clin. Sarcoma Res. 2013, 3, 5. [CrossRef] [PubMed]

122. Miyagawa, T.; Kadono, T.; Kimura, T.; Saigusa, R.; Yoshizaki, A.; Miyagaki, T.; Yamada, D.; Masui, Y.; Fujita, H.; Sato, S. Pazopanib induced a partial response in a patient with metastatic fibrosarcomatous dermatofibrosarcoma protuberans without genetic translocations resistant to mesna, doxorubicin, ifosfamide and dacarbazine chemotherapy and gemcitabine-docetaxel chemotherapy. J. Dermatol. 2017, 44, e21-e22. [CrossRef] [PubMed]

123. Tsuchihashi, K.; Kusaba, H.; Yamada, Y.; Okumura, Y.; Shimokawa, H.; Komoda, M.; Uchino, K.; Yoshihiro, T.; Tsuruta, N.; Hanamura, F.; et al. Programmed death-ligand 1 expression is associated with fibrosarcomatous transformation of dermatofibrosarcoma protuberans. Mol. Clin. Oncol. 2017, 6, 665-668. [CrossRef] [PubMed]

124. Ohaegbulam, K.C.; Assal, A.; Lazar-Molnar, E.; Yao, Y.; Zang, X. Human cancer immunotherapy with antibodies to the PD-1 and PD-L1 pathway. Trends Mol. Med. 2015, 21, 24-33. [CrossRef] [PubMed]

(C) 2020 by the authors. Licensee MDPI, Basel, Switzerland. This article is an open access article distributed under the terms and conditions of the Creative Commons Attribution (CC BY) license (http://creativecommons.org/licenses/by/4.0/). 